\title{
Integration of the environmental management aspect in the optimization of the design and planning of energy systems
}

\author{
Giorgos Theodosiou ${ }^{a}$, Nikolaos Stylos ${ }^{b}$, Christopher Koroneos ${ }^{\text {at }}$ \\ ${ }^{\text {a }}$ Laboratory of Heat Transfer and Environmental Engineering, Aristotle University of Thessaloniki, P.O. Box 487, GR 54124 \\ Thessaloniki, Greece \\ ${ }^{\mathrm{b}}$ Department for Marketing, Innovation, Leisure and Enterprise, University of Wolverhampton Business School, University \\ of Wolverhampton, MN Building, Nursery Street, Wolverhampton WV1 1AD, UK
}

${ }^{\dagger}$ Corresponding author (koroneos@ chemeng.ntua.gr)

\begin{abstract}
The increasing concerns regarding the environmental pollution derived from anthropogenic activities, such as the use of fossil fuels for power generation, has driven many interested parties to seek different alternatives, e.g. use of renewable energy sources, use of "cleaner" fuels and use of more effective technologies, in order to minimize and control the quantity of emissions that are produced during the life cycle of conventional energy sources. In addition to these alternatives, the use of an integrated procedure in which the environmental aspect will be taken into account during the design and planning of energy systems could provide a basis on which emissions reduction will be dealt with a life cycle approach. The work presented in this paper focuses on the examination of the possibilities of integrating the environmental aspects in the preliminary phase of the conventional design and planning of energy systems in conjunction with other parameters, such as financial cost, availability, capacity, location, etc. The integration of the environmental parameter to the design is carried out within a context where Eco-design concepts are applied. Due to the multi-parameter nature of the design procedure, the tools that are used are Life Cycle Analysis and Multi-criteria Analysis. The proposed optimization model examines and identifies optimum available options of the use of different energy sources and technologies for the production of electricity and/or heat by minimizing both the financial cost and the environmental impacts, with regard to a multiple objective optimization subject to a set of specific constraints. Implementation of the proposed model in the form of a case study for the island of Rhodes in Greece revealed that an optimized solution both cost and environmental-wise, would be an almost balanced participation of renewables and non-renewable energy sources in the energy mix.
\end{abstract}

Keywords: Eco-design, energy systems design, life cycle analysis, multi-objective optimization

\section{Introduction}

Energy is one of the most important resources that determine the evolution of economy and technology worldwide (Rivers and Jaccard, 2005; Theodosiou et al., 2014). The transition from the industrial to the technological revolution emphasizes even more the important role of electric energy, because the sum of all the financial and economic activities depends directly on it and any 
development coincides with an increasing demand of electricity (Kooijman-van Dijk \& Clancy, 2010). Electric energy as a conversion product of other energy sources highlights in turn the importance of primary energy resources. An energy system can be defined as the connection, in a physical way, of the energy generation/conversion facilities (e.g. electricity, heat), the storage facilities, the transmission and the distribution ones that operate as a complete system (Liu et al., 2010). The design of energy systems constitutes a procedure of selecting the energy sources and technologies required for the conversion/generation, transmission and distribution processes, in order to meet specific energy needs (Andrews and Shabani, 2012; Sieniutycz and Jezowski, 2009). Conventional design of energy systems is determined by a number of parameters, such as geographical location, availability and the capacity of the energy sources that will be used, generation cost, available technologies, and etc. (Pudjianto et al., 2007). Until today, the need for electricity is met mainly from exploitation of fossil/conventional energy sources, i.e. coal, natural gas and petroleum (Wang et al., 2007; Boudghene Stambouli and Traversa, 2002). During the last years, use of renewable energy sources (RES), cleaner fuels and more effective technologies (e.g. cogeneration) for electricity generation is increasing, mainly due to depletion of fossil fuels reserves, geopolitical reasons and environmental pollution (Chicco and Mancarella, 2009a; Kirubakaran et al., 2009; Kumar et al., 2009; Yusoff, 2006; Barreto et al., 2003). Therefore, it seems that the increasing demand for electric energy in conjunction with the factors that determine the future of fossil fuels support the necessity for changes in energy policy and planning, as well as in the design of power generation systems (Jacobson and Delucchi, 2011).

The work presented in this paper is oriented towards examining the possibilities of minimizing the environmental impacts that derive from use of different energy sources for electricity and/or heat generation through the optimization of energy systems design and planning. Based on the conventional procedure that is followed when an energy system is designed, the environmental requirements are taken into account later on, in the system development process (Vinodh \& Rathod, 2010; Dovì et al., 2009; Kjaerheim, 2005; Kaebernick et al., 2002). The usefulness of incorporating environmental performance parameters in the early design and planning phase has been emphasized in several research articles (Vinodh \& Rathod, 2010; Gehin et al., 2008; Millet et al., 2007; Scheuer et al., 2003). In those articles it is supported that sustainable design is important because it promotes proactive development of synthesizing abilities (Karlsson \& Luttropp, 2006) and it helps designers make optimal decisions considering end-of-life strategies (Gehin et al., 2008). It is widely known that greenhouse gas (GHG) emissions, pollutants released in water (e.g. nitrogen and phosphorous) and various wastes deposited on soil during power production have a major negative impact on global climate (Thitakamol et al., 2007; von Blottnitz \& Curran, 2007; Driscoll et al., 2003). Therefore, any measures or actions taken in order to minimize and control environmental pollution through techniques such as Best Available Techniques (Liu \& Wen, 2012; Bréchet \& Tulkens, 2009; Wilde, 2008; Georgopoulou et al., 2007), are mainly end-of-the-pipe solutions and are restricted to dealing with the problem during the operation of the power plants (Giner-Santonja et al., 2012). Odeh et al. (2008) state that in many cases these actions could result in reduction of the amount of emissions and pollutants released during the power generation stage of life cycle, but on the other hand they could increase the total environmental impacts of the life cycle overall. In addition to this, these efforts could prove very costly for implementation (Khan et al., 2001). Graedel and Allenby (1995) state that the environmental performance of an energy system is determined at its greatest extent in the design phase and from the options that are available in this phase. Thus, although the exclusive use of RES for 
power generation seems to be the obvious answer to the problem of environmental pollution it does not actually constitute a feasible or reliable solution to cover every demand for energy ( $\mathrm{Li}, 2005)$. This is due to the technological restrictions and the financial cost that are related with the use of RES for large scale electricity generation, although the financial incentives given for the exploitation of RES are becoming more and more attractive (Liming, 2009; Reddy \& Painuly, 2004). Therefore, a more holistic approach is needed in order to examine the problem of environmental pollution and energy systems design (Cashmore, 2004). This can be done by looking at the whole life cycle of the energy system, by including concepts such as LCA and Eco-design (Thabrew et al., 2009; Seager \& Theis, 2002). The proposed approach will provide an acceptable and feasible solution that will constitute a compromise of the technological restrictions, the financial cost and the minimization of the environmental impacts (Knight \& Jenkins, 2009). Moreover, it can be adopted by following a specific ecological design procedure for energy systems, namely a procedure that will involve the environmental aspects to be integrated and applied at the very early stages of conventional design and decision making process. On this basis, an energy systems design and planning optimization model has been developed and presented in this work that uses the tools of life cycle analysis (LCA) (ISO, 1997; SETAC, 1993) and multi-criteria analysis in order to provide a framework where the environmental aspect can be incorporated in the conventional design (Fig. 1). LCA is a tool that plays a major role in the eco-design concept and enables the quantification of all environmental impacts related to life cycle of an energy source used in electricity generation, the identification of the sections that need the most attention and the assessment and evaluation of the improvement options (Blengini \& Di Carlo, 2010; Luttropp \& Lagerstedt, 2006). Multi-criteria analysis is a suitable methodology for solving multi-parameter problems in which the selection of an acceptable solution is depending on the optimization criteria chosen for each different case (Dall'O et al., 2013). Therefore, although there are available several optimization models published during the last decade (Kowalski et al., 2009; Papadopoulos \& Karagiannidis, 2008; Giampietro et al., 2006; Polatidis et al., 2006; Lazzaretto \& Toffolo, 2004; Haralambopoulos \& Polatidis, 2003), the proposed multi-criteria analysis model combines the LCA tool with a financial analysis tool to provide an optimum feasible and acceptable solution for the design of an energy system. 


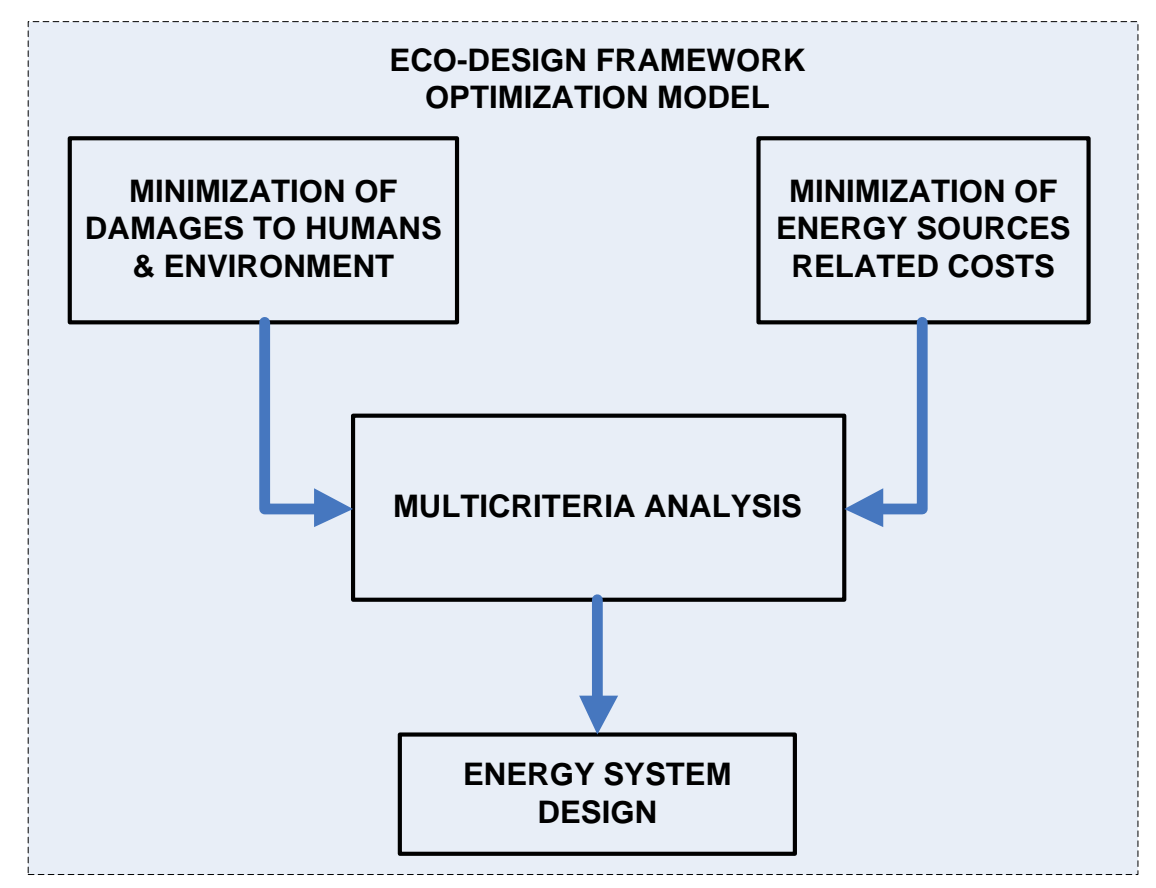

Fig.1. Eco-design framework and integration of the environmental aspect as a parameter for minimization.

\section{Theory}

Various LCA-related concepts, methods and models have been suggested by researchers covering the sustainability dimensions (environment, economic, social, and institutional) in a combined way or independently and with different foci (product, project, policy level) (Jeswani et al., 2010; Iribarren and Vázquez-Rowe, 2013). Eco-design and LCA have been used in the past mainly in studies of environmental assessment of products for the improvement of their design (Karlsson and Luttropp, 2006). They have progressively started to find application in the field of power generation (Wang et al., 2013), while it is quoted in literature that they are suitable to be used for the environmental assessment of the life cycle of different energy sources and technologies (Stylos and Koroneos, 2014; Bravi and Basosi, 2013; Demir and Taşkin, 2013). Relevant research concerns electricity generation, as well as environmental assessment and design of energy systems in general (Clift, 1998; Pesso, 1993; Lee at al., 1995; Azapagic, 1999; Azapagic and Clift, 1999; Matsuhashi et al., 1996; Benetto et al., 2004; Keoleian, 1993; Khan et al., 2002; Lombardi, 2002; Furuholt, 1995; Kyriakis et al., 2004; Theodosiou et al., 2005a; Theodosiou et al., 2005b; Sheehan et al., 1996; Golonka and Brennan, 1996; Alexander et al., 2000). Some of the research efforts concerning environmental assessment in the field of electricity generation are restricted in the operation stage of the power plants and in the creation of an inventory of inputs and outputs (mass, energy and emissions) (Pacca \& Horvath, 2002). In other words, in those cases these inputs and outputs are not associated with the environmental impacts of the production process e.g. a total environmental performance score or index.

Associating the inputs and outputs of the inventory phase of the total life cycle with the environmental impacts through suitable factors like the ones proposed in Eco-indicator 99 method (Goedkoop et al., 2000; Goedkoop \& Spriensma, 2001) can be very useful in order to identify the areas where the most improvements need to be made. Using the life cycle approach, i.e. examining the complete life cycle of an energy source / energy system, ensures that all inputs and outputs of all the 
stages of a system are examined and included in the analysis (Huntzinger \& Eatmon, 2009; Hutchins \& Sutherland, 2008). Thus, results are more realistic and comprehensive and it is easier to identify which stages of the life cycle contribute more to the total environmental performance and to the individual impact and damage categories. A complete description of the LCA methodology can be found in SETAC's and ISO's guidelines (ISO, 1997; SETAC, 1993) and for the Eco-indicator 99 method in PRe's manual (Goedkoop et al., 2000; Goedkoop \& Spriensma, 2001).

The problem of the rational allocation and use of energy sources is a multi-parameter one (Wang et al., 2008). It is directly related to the design and planning of energy systems and energy policies in order to meet specific energy needs and to protect the environment at the same time (Greening and Bernow, 2004). It includes parameters and restrictions such as the available technologies, legislation, availability and capacity of energy sources and systems, environmental impacts and financial cost (Jebaraj and Iniyan, 2006). Multi-criteria analysis is a suitable method for solving this type of problems and it has been used in many cases for solving problems related to the optimization of design and planning of energy systems (Diakoulaki et al., 2005; Beccali et al., 1998; Giannantoni et al. 2005; Karaggelis, 2004; Bogetoft and Pruzan, 1997; Belton and Stewart, 2002; Catrinu, 2006; Ribeiro, 1996). Nevertheless, in many cases the data used in the optimization involve technological and financial parameters and do not include the environmental impacts. In case the environmental impacts are included, this is done in the restrictions and not as a parameter that has to be minimized along with the financial cost (Azar et al., 2003).

Energy systems design and planning for covering specific energy needs constitute a composite procedure where different energy sources are selected in an alternative or supplementary manner, depending on local parameters of potential energy supply/demand and environmental impacts (Mohammad Rozali et al., 2013; Lim et al., 2013; Faé Gomes et al., 2012; Pękala et al., 2010; de Lucena et al., 2010). The formulation of energy models contributes to the design of energy systems and it has drawn the attention of many scientists and decision makers over the last 40 years (Taha and Daim, 2013; Kaya and Kahraman, 2011; Liu et al., 2009; Santarelli et al., 2004; Böhringer, 1998; Ramakumar et al., 1992; Daniel and Goldberg, 1981). During the 70's all relative efforts were directed towards formulating energy models associated with the investigation of relations between energy and economy (Hartman, 1979; Manne et al., 1979); those relations were explored in the electricity generation sector after the oil crisis (Samouilidis and Mitropoulos, 1982; Meier and Mubayi, 1983; Kydes, 1990; Zionts and Deshpande, 1978). The main objectives that were set in that period were the exact determination of the future energy demand and the identification of the most effective options of energy supply through single criteria approaches that were based in the minimization of the financial cost (Wack, 1985; McDougall et al., 1981). During the 80's, increasing concern for the environmental pollution modified somewhat the previous design and decision making framework (Van Liere and Dunlap, 1981; Albrecht et al., 1982; Nijkamp and Volwahsen, 1990). Actually, the need for incorporating the environmental impacts in energy systems design resulted in the increasing use of multi-criteria approaches (Østergaard, 2009). On one hand, linear multiple objectives models have been used to determine the field and the effects of feasible actions, to present the interactions between economic and environmental parameters and to aid the selection of a compromising solution (Kavrakoglu, 1983; Schulz and Stehfest, 1984). On the other, many studies were devoted in the evaluation of different energy alternatives regarding multi-criteria problems and succeeded in 
clarifying the contrasts related with energy decisions (Siskos and Hubert, 1983; Roy and Bouyssou, 1986; Hartog et al., 1989).

Energy systems models can be classified in many ways. A common classification is given by Hiremath et al. (2007), Markandya (1990) and Jebaraj and Iniyan (2006), where six main categories are used: (i) Energy design/planning models, (ii) Energy demand - supply models, (iii) Energy forecasting models (commercial and renewable energy), (iv) Energy models based on neural networks (fuzzy based multi-objective analysis), (v) Emission abatement models, (vi) Energy systems optimization models. From a broader point of view the following alternative types of energy system models can be met (Bhattacharyya and Timilsina, 2010): bottom-up optimization-based models, bottom-up accounting models, top-down econometric models, hybrid models and electricity system models (such as Electricity Generation Expansion Analysis System, EGEAS).

The research interest of the present work is focused mainly in the energy systems optimization models. Many studies can be found in literature where different variations of this type of models have been developed in order to aid the design of energy systems used to cover specific energy needs and in which the multi-criteria analysis is used (Kydes, 1990; Psarras et al., 1990; Tiris et al., 1994; Lehtila, 1996; Khella, 1997; Georgopoulou et al., 1998; Kaldellis and Kavadias, 2001; Soloveitchik et al., 2002; Cormio et al., 2003; Raiko et al., 2003; Koroneos et al., 2004; Koroneos et al., 2005, Diakoulaki and Karangelis, 2007).

The main differences of the various models that have been developed are focused on the following (see Table 1):

Table 1

Criteria for classifying energy systems optimization models and relevant options.

\begin{tabular}{|c|c|c|}
\hline Criteria & General Option 1 & General Option 2 \\
\hline Time horizon & $\begin{array}{l}\text { Short to medium term (Mueller- } \\
\text { Langer et al., 2007; Metaxiotis et } \\
\text { al., 2003; Shawwash et al., 2000) }\end{array}$ & $\begin{array}{l}\text { Medium to Long term (Turton and } \\
\text { Barreto, 2006; Ghiassi et al., 2006; } \\
\text { Thorin et al., 2005) }\end{array}$ \\
\hline Energy sources \& technologies & $\begin{array}{l}\text { Efficient Fossil fuel technologies } \\
\text { (Riaz et al., 2013; Descamps et al., } \\
\text { 2008; Rosen, 2001) }\end{array}$ & $\begin{array}{l}\text { Renewable energy sources or } \\
\text { cogeneration with fossil fuel sources } \\
\text { (Xydis, 2013; Banos et al., 2011; } \\
\text { Mormirlan and Veziroglu, 2005) }\end{array}$ \\
\hline Restrictions considered & $\begin{array}{l}\text { Technological, availability of } \\
\text { resources (Kaldellis et al., 2009; } \\
\text { Cai et al., 2009; Lund et al., 2007) }\end{array}$ & $\begin{array}{l}\text { Environmental, social, institutional- } \\
\text { policies (Santibañez-Aguilar et al., } \\
\text { 2013; Bazmi and Zahedi, 2011; Gong } \\
\text { et al., 2010) }\end{array}$ \\
\hline Range of applications & $\begin{array}{l}\text { Small scale (Skarlis et al., 2012; } \\
\text { Chicco and Mancarella, 2009b; } \\
\text { Dondi et al., 2008) }\end{array}$ & $\begin{array}{l}\text { Large scale (Djuric Ilic et al., 2014; } \\
\text { Muñoz and von Spakovsky, 2010; } \\
\text { Lund, 2005) }\end{array}$ \\
\hline Purpose of applications & $\begin{array}{l}\text { Policy making (Vikhorev et al., } \\
\text { 2013; Therkelsen et al., 2013; Lin } \\
\text { et al., 2009) }\end{array}$ & $\begin{array}{l}\text { Electricity and/or heat demands of a } \\
\text { specific location (Moradi and Abedini, } \\
\text { 2012; Cucchiella et al., 2013; Ren et } \\
\text { al., 2010) }\end{array}$ \\
\hline Parameter(s) optimized & $\begin{array}{l}\text { Financial cost (Delucchi and } \\
\text { Jacobson, 2011; Rentizelas et al., } \\
\text { 2009; Maceira et al., 2002) }\end{array}$ & $\begin{array}{l}\text { Financial cost \& environmental } \\
\text { impacts (Debacker et al., 2013; } \\
\text { Kaldellis et al., 2009; González- } \\
\text { Monroy and Cordoba, 2002) }\end{array}$ \\
\hline Involvement of environmental parameter & $\begin{array}{l}\text { As an additional restriction (Wang } \\
\text { and Singh, 2008; Muela et al., } \\
\text { 2007; Narodoslawsky and } \\
\text { Krotscheck, 2004) }\end{array}$ & $\begin{array}{l}\text { Minimization (Zuwała, 2012; Ochoa } \\
\text { and Harrison, 2011; Pehnt, 2006) }\end{array}$ \\
\hline
\end{tabular}


- the energy sources and technologies used for electricity and/or heat generation under examination (e.g. only fossil fuels or only RES, and in some cases both)

- the horizon involved concerning the time frame of deploying the optimized solutions (e.g. short, medium or long term)

- the various restrictions being considered (technological, social, capacity, availability, etc.)

- the range of applications (small or large scale) and the purpose of applications (e.g. design of an energy system of a country and policy making, design of an energy system to cover the electricity and/or heat demands of an island or a smaller area)

- the parameter that is optimized. In most cases the main objective is the financial cost minimization, although as already stated, the need of incorporating the environmental aspect is becoming more and more imperative,

- the way that the environmental parameter is incorporated. In most cases where the environmental aspect is also included in the model, this is done with a different way. It is mainly incorporated as a restriction and not as an objective function that has to be minimized together with the financial cost objective function.

\section{Materials and methods}

The optimization model presented in this paper aims to associate all the aforementioned characteristics within a single methodology and to contribute to the efforts being made towards enhancement of environmental protection.

As already stated, the data required for the environmental evaluation of the total life cycle related to an energy system are obtained with the application of the LCA tool (De Benedetto, L. and Klemeš, 2009). The corresponding financial data needed can be obtained through an economic analysis of the alternatives offered in the market. This analysis should include the electricity and/or heat generation cost but it can also include two additional costs; the cost for exceeding limitations of emissions allowances and the 'external cost', which associates the environmental impacts with economic values, forms an issue that has been examined in many studies (Georgakellos, 2012; Ladenburg and Dubgaard, 2007; Tanzil and Beloff, 2006; Krewitt, 2002; Golonka and Brennan, 1997; European Commission, 1995; Huppes, 1996; Boustead, 1995; Golonka, 1996; Kniel, 1996; Baasel, 1985; Delaby and Smith, 1995).

The optimization model is formulated in such a way that it can be used at the preliminary design of a new energy system as well as for the assessment of the environmental performance of an existing one. The environmental assessment of existing energy systems may be performed in order to investigate and evaluate the expansion possibilities or to evaluate the environmental performance and replacement of an individual process (Varun et al., 2009; Hur et al., 2005). A simplified design procedure of a new power generation system or a revised existing energy system is shown in Fig. 2. The integration of LCA as the basic tool of Eco-design does not change the conventional procedure but on the contrary it adds the data required for the design of environmentally more friendly energy 
systems. Fig. 3 shows the basic form of the centralized electricity generation model while Fig. 4 presents a modification of the model. In order to cover the energy needs of a region, electricity from a central network is used as well as electricity and/or heat from energy systems that are installed locally.

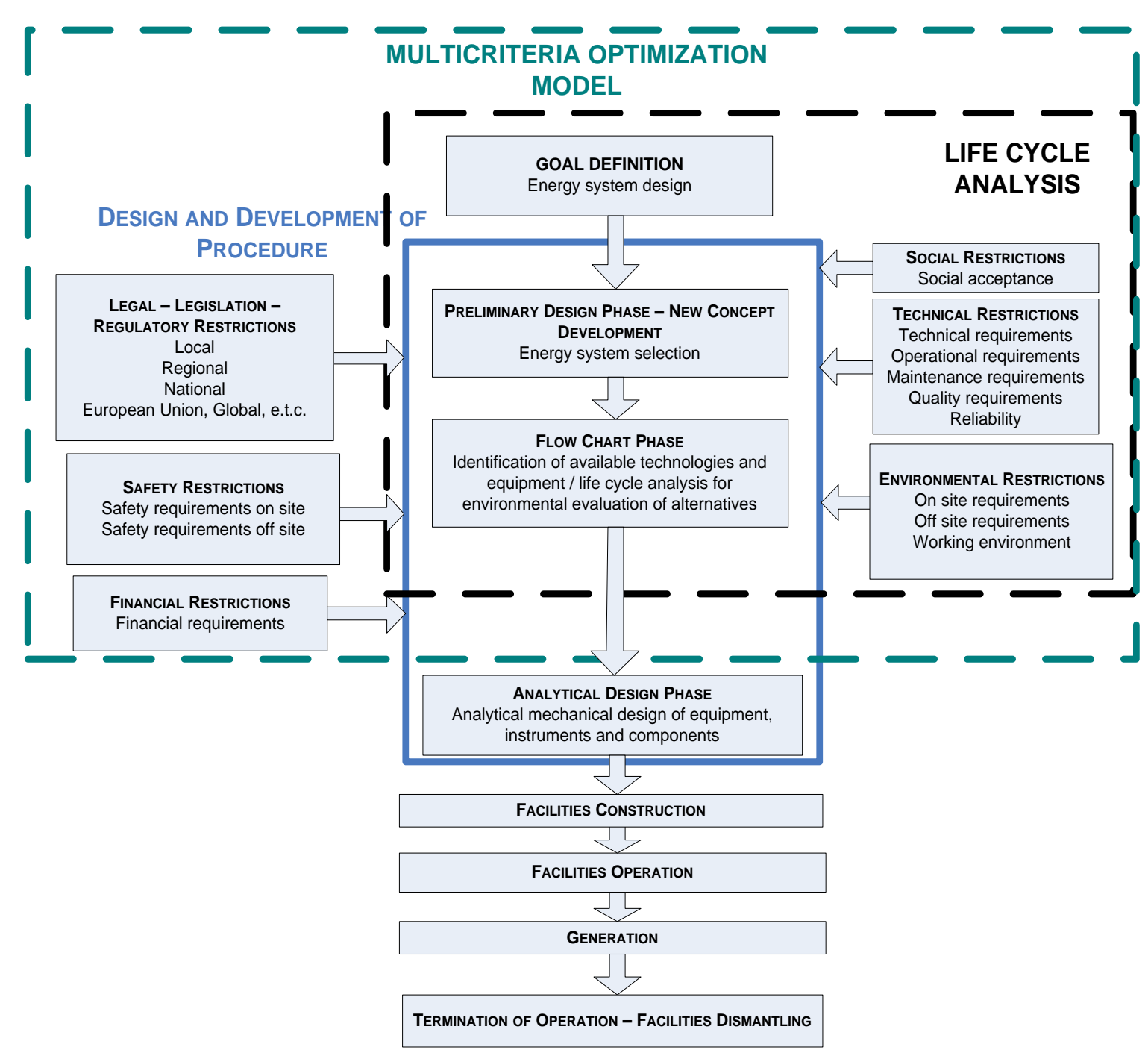

Fig.2. Simplified design procedure of a new energy system. 


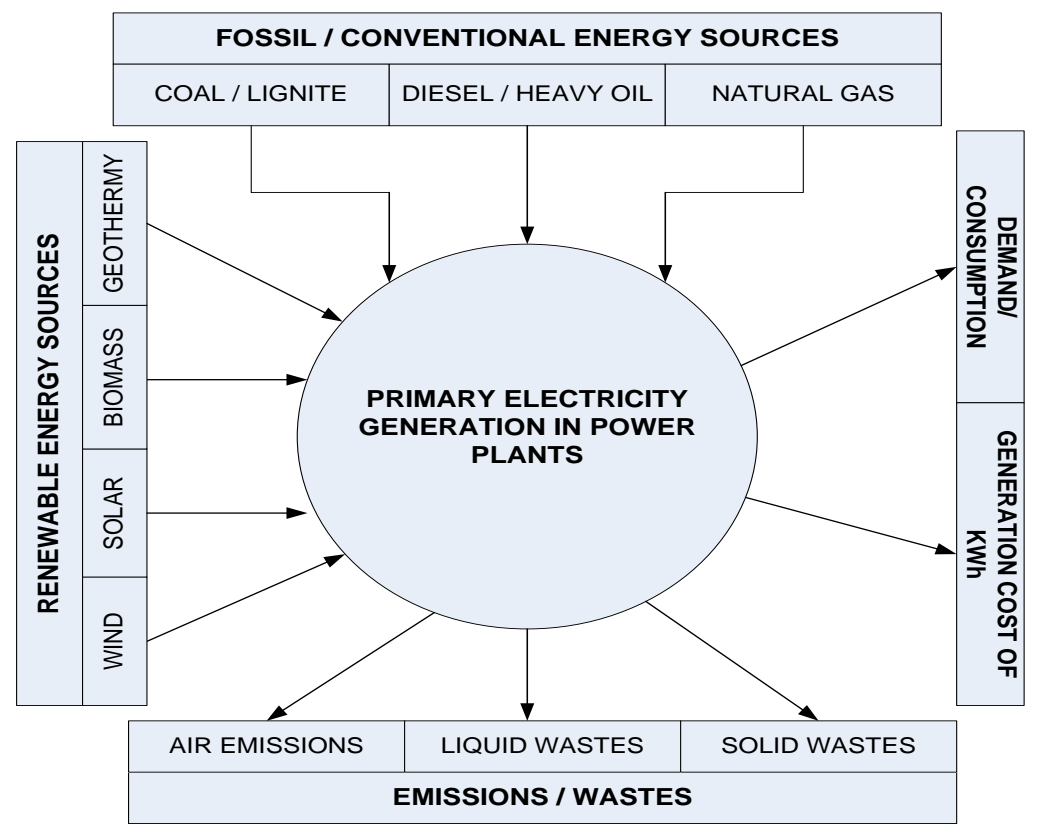

Fig. 3: Basic electricity generation model representation.

The relevant methodology in developing the optimization model is a "black box" approach, meaning the analysis is macroscopic (it is not focused in the optimization of a specific process, e.g. in a thermodynamic aspect of a power plant) (Chicco and Mancarella, 2009a; Babbitt and Lindner, 2005). The general steps of the design of an energy system are presented in Fig. 5. The basic aspects that formulate the optimization model are:

- Availability of energy sources - Depending on the geographic location of a region, the corresponding availability for both the energy sources and the electricity and/or heat generation technologies that can be used are determined,

- Electricity generation cost - The electricity generation cost of a specific technology or energy source depends on many parameters and is not often fixed. This cost is related directly with the energy source cost, the availability of an energy source, the efficiency of an energy system and also with the exploitation and to the extent the technology is used. In many cases, the external cost and the cost of excess of the limitations of emissions allowances can also be included in the total cost,

- Environmental impacts - They depend directly on the energy source used and on the type and efficiency of the technology embodied in the energy system,

- Percentage use of RES - Due to legislations, directives, policies and strategies both at a national and European Union (EU) level, the use of RES in the electricity generation sector should gradually increase during the forthcoming years, and

- Electricity demand and supply. 


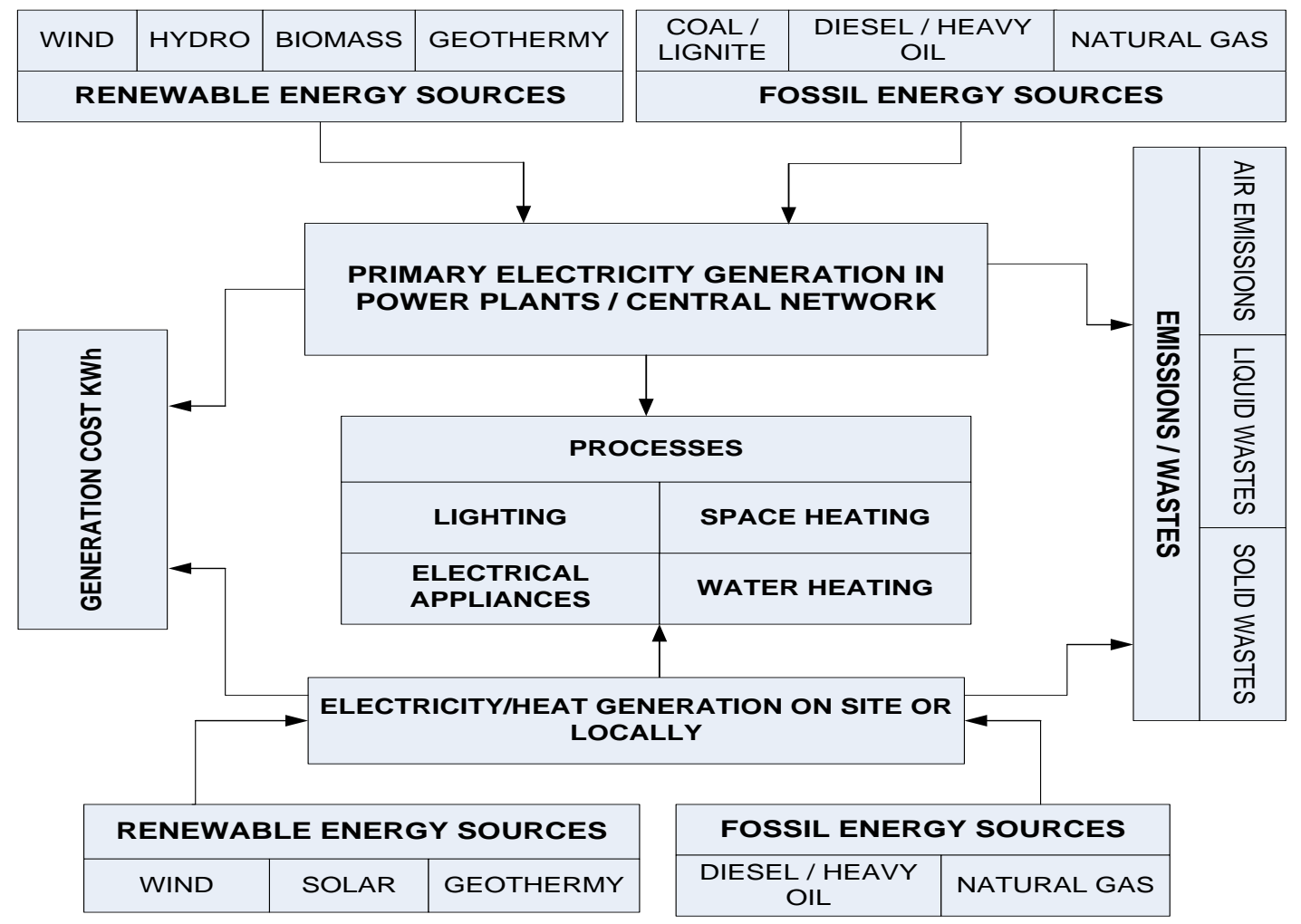

Fig.4. Variation of the electricity generation model where in order to cover the energy needs of a region or of facilities of smaller scale, electricity from a central network is used as well as electricity and/or heat from energy systems that are installed.

The goal of this procedure is the minimization of the two main aspects associated with electricity and/or heat generation, which are the financial cost and the environmental impacts. These two aspects are directly related. Electricity and/or heat generation from fossil fuels involves lower cost but higher quantities of emitted pollutants. On the other hand, the use of cleaner technologies such as RES involves lower environmental impacts, but due to the lower energy density in which these energy sources are available the cost increases (Hadjipaschalis et al., 2009). In multi-criteria problems, there is not a single criterion that can describe adequately the consequences of each alternative (Greening and Bernow, 2004). Also, it cannot be claimed a single optimum solution for all objectives, due to the fact that in most cases they are in conflict (Van Veldhuizen and Lamont, 2000). The set of optimum solutions that result do not correspond to solutions that reflect the minimum environmental impacts (minimum quantities of emitted pollutants) or the minimum financial cost (Banos et al., 2011; Gebreslassie et al., 2009; Kaldellis and Zafirakis, 2007; Hugo et al., 2005; Pohekar and Ramachandran, 2004. They correspond to solutions that represent a compromise of these two parameters. 


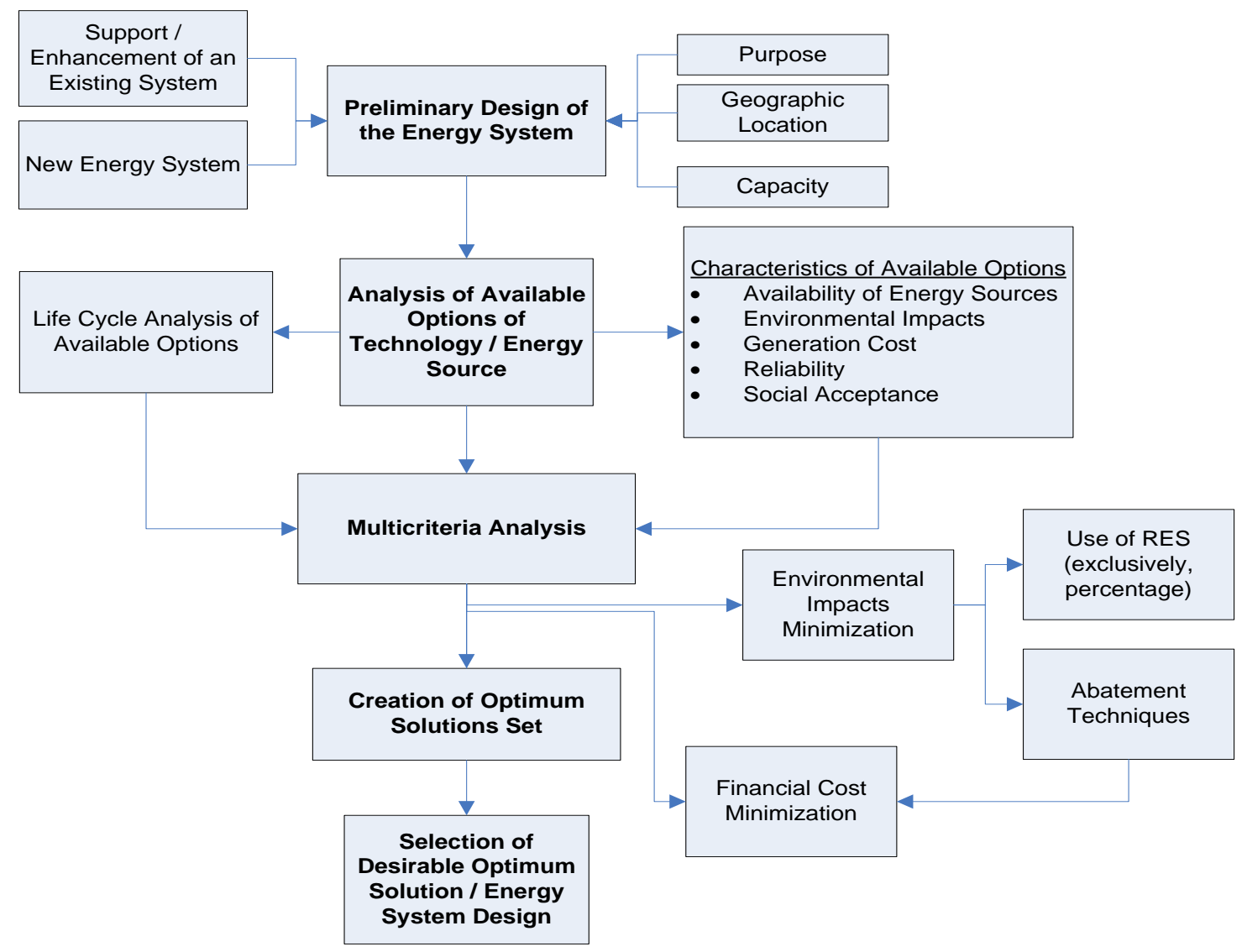

Fig.5. General steps for the design of an energy system based on the life cycle analysis methodology and multi-criteria analysis model.

\subsection{Calculations}

The general procedure for the multi-criteria optimization model formulation that is accompanied by the relevant restrictions, related to the available alternatives, is shown in Fig.6. Also, the objective functions that have to be minimized using the data from the environmental and financial analysis are described. The symbols that represent all variables participating in the system of equations are explained below:

$n$.... the available energy sources / energy systems (RES and conventional) for electricity generation $m \ldots$... the available energy sources / energy systems (RES) for electricity generation

$k \ldots$... the available energy sources / energy systems for heat generation

$P_{i}, \mathrm{i}=0,1,2, \ldots \mathrm{n}$, the optimum electricity generation from an energy source / energy system

$Q_{l}, 1=0,1,2, \ldots \mathrm{k}$, the optimum heat generation from an energy source / energy system

$D_{i}, \mathrm{i}=1,2, \ldots \mathrm{n}$, the energy demand (electricity or heat)

$C_{i}, \mathrm{i}=0,1,2, \ldots \mathrm{n}$, the electricity generation financial cost

$F_{l}, 1=0,1,2, \ldots \mathrm{k}$, the heat generation financial cost

$K_{i}, \mathrm{i}=0,1,2, \ldots \mathrm{n}$, the cost of excess of the limitations of emissions allowances and the external cost of electricity generation 
$M_{i}, \mathrm{i}=0,1,2, \ldots \mathrm{n}$, the maximum energy generation capacity (electricity and heat)

$E_{i}, \mathrm{i}=0,1,2, \ldots \mathrm{n}$, the environmental impacts for energy generation that are expressed as total environmental evaluation indices of electricity and/or heat generation energy systems

$S_{i}, \mathrm{i}=0,1,2, \ldots \mathrm{n}$, the social acceptance for an energy source / energy system

$R_{i}, \mathrm{i}=0,1,2, \ldots \mathrm{n}$, the reliability of an energy system

$Z_{i}, \mathrm{i}=0,1,2, \ldots \mathrm{n}$, the objective functions

$L$... the use percentage of RES technologies determined by legislation (mainly for large systems)

$W_{i} \ldots$ the emissions of the life cycle of an energy source / energy system

Cost variables are expressed in euros $(€)$, energy in the forms of primary energy carriers, electricity, and heat are measured in $\mathrm{kWh}$ and reliability is measured in mean operating time between failures (MTBF).

\subsection{Environmental management aspect integration}

The environmental aspect is integrated in the multi-criteria optimization model as an objective function that has to be minimized together with the objective function of the financial cost. The general form of this function is given in equation 1 :

$$
\mathrm{f}(\mathrm{x})=\sum_{\mathrm{i}}^{\mathrm{n}} P_{i} * E_{i} \quad i=0,1,2 \ldots n
$$

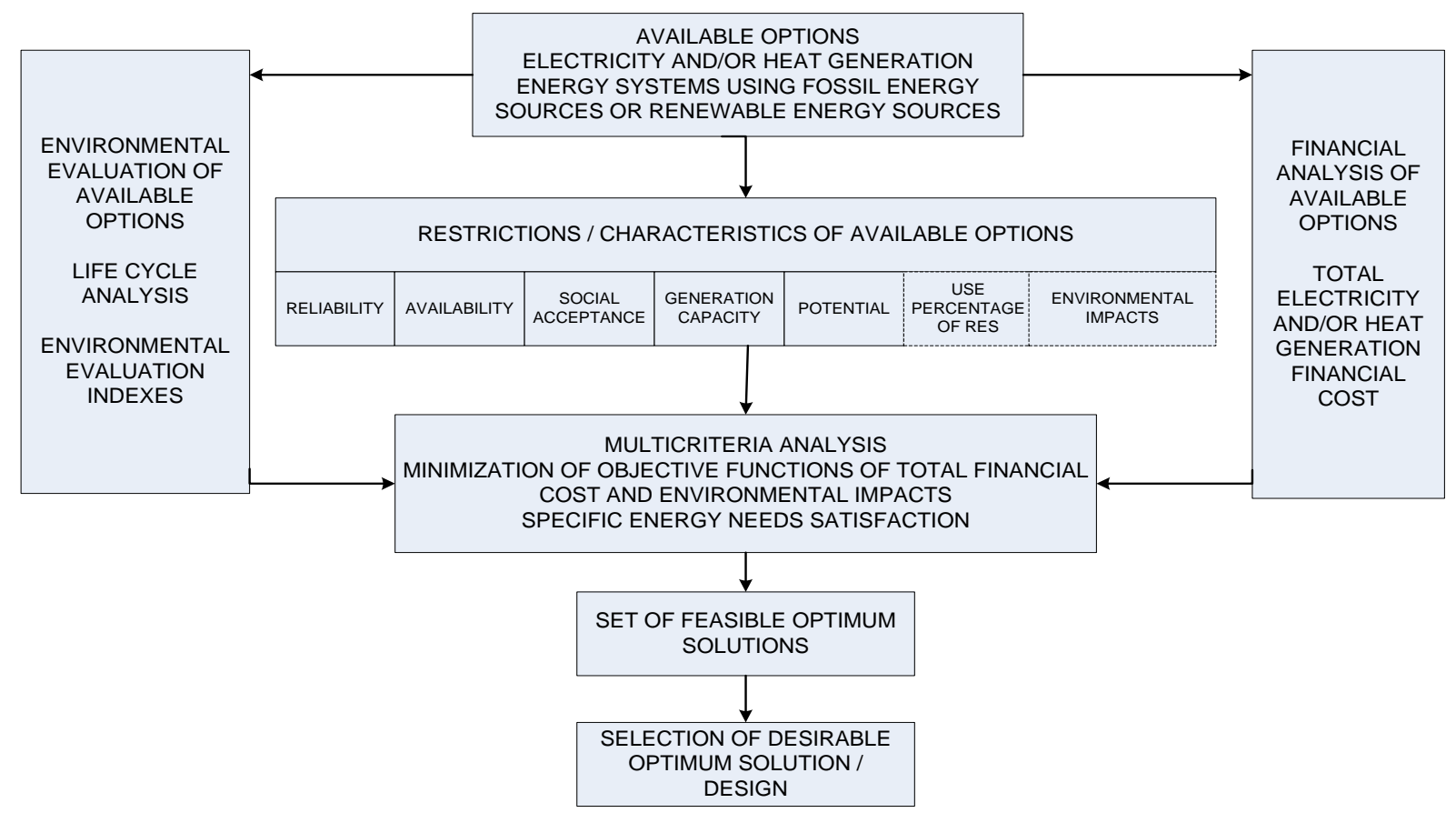

Fig.6. General procedure of the mathematical problem and multi-criteria optimization model formulation. 
The $E_{i}$ refers to the environmental evaluation index resulting from the application of LCA and the association of the emitted pollutants with their environmental impacts. Depending on the particularity of each problem and the preferences of the designer, $E_{i}$ can represent the quantity of pollutants emitted either overall from the total life cycle of the energy system / source or from each stage of the life cycle individually expressed as $W_{i}$. The conversion of the quantity of emitted pollutants $W_{i}$ to the environmental evaluation indices $\mathrm{E}_{i}$ is performed through the classification, characterization, normalization and evaluation factors of the Eco-Indicator 99 methodology. When the emissions (quantities not indices) are used in the model, $W_{i}$ could be referring to either the total quantities of pollutants emitted for a time period, and for a specific amount of electricity ( $\mathrm{kg} / \mathrm{MWh}$ or $\mathrm{kg} / \mathrm{MJ}$ ) or to the heat and electricity generated. It could also refer to the quantity of pollutants emitted from the total life cycle or from the individual stages of the life cycle. Figure 7 presents the life cycle stages of different energy sources and technologies used for electricity and/or heat generation as well as the emissions of each stage. The total emissions $W_{i}$ for the life cycle of each energy source are given in equations $2-9$ :

$W_{0}=W_{0 A}+W_{0 M}+W_{0 \Lambda}+W_{0 \mathrm{~K}} \ldots$. Coal/Lignite

$W_{1}=W_{1 A}+W_{1 \mathrm{E}}+W_{1 M}+W_{1 \Lambda}+W_{1 \mathrm{~K}} \ldots$. Petroleum

$W_{2}=W_{2 A}+W_{2 M}+W_{2 \Lambda}+W_{2 \mathrm{~K}} \ldots$. Natural gas

$W_{3}=W_{3 A}+W_{3 \mathrm{E}}+W_{3 M}+W_{3 \Lambda}+W_{3 \mathrm{~K}} \ldots$. Wing energy

$W_{4}=W_{4 \Lambda}+W_{4 \mathrm{~K}} \ldots$. Hydroelectric energy

$W_{5}=W_{5 A}+W_{5 \Lambda}+W_{5 \mathrm{~K}} \ldots$. Geothermal energy

$W_{6}=W_{6 A}+W_{6 M}+W_{6 \Lambda}+W_{6 \mathrm{~K}} \ldots$. Biomass

$W_{7}=W_{7 A}+W_{7 \mathrm{E}}+W_{7 M}+W_{7 \Lambda}+W_{7 \mathrm{~K}} \ldots$. Solar energy / Photovoltaics \& Solar Collectors

where,

$W_{i A}=$ pollutants released during extraction or acquisition of $i$ energy form $(i=0,1,2,3,5,6,7)$

$W_{i E} \quad=$ pollutants released during manufacturing and processing for $i$ energy form $(i=1,3,7)$

$W_{i M}=$ pollutants released during transportation to generation facilities for $i$ energy form $(i=0,1,2,6)$

$W_{i K}=$ pollutants released during facilities construction $\&$ dismantling and termination of operation for $i$ energy form $(i=0,1,2,3,4,5,6,7)$

$W_{i \Lambda}=$ pollutants released during system operation / electricity generation for $i$ energy form $(i=0,1,2,3$, $4,5,6,7)$

The distinction between total life cycle emissions and emissions produced during each stage of the life cycle of the energy sources could be useful. The usefulness could be seen in case the design goal is the reduction of specific pollutants that stem from specific stages of the life cycle; it is associated with 
the importance and contribution of these pollutants to the energy systems' environmental profile during a specific time period and within a definite geographical region. The objective function that expresses the environmental aspect in this case is given in equation 10:

$$
\mathrm{f}(\mathrm{x})=\sum_{\mathrm{i}}^{\mathrm{n}} P_{i} * W_{i} \quad i=0,1,2 \ldots n
$$

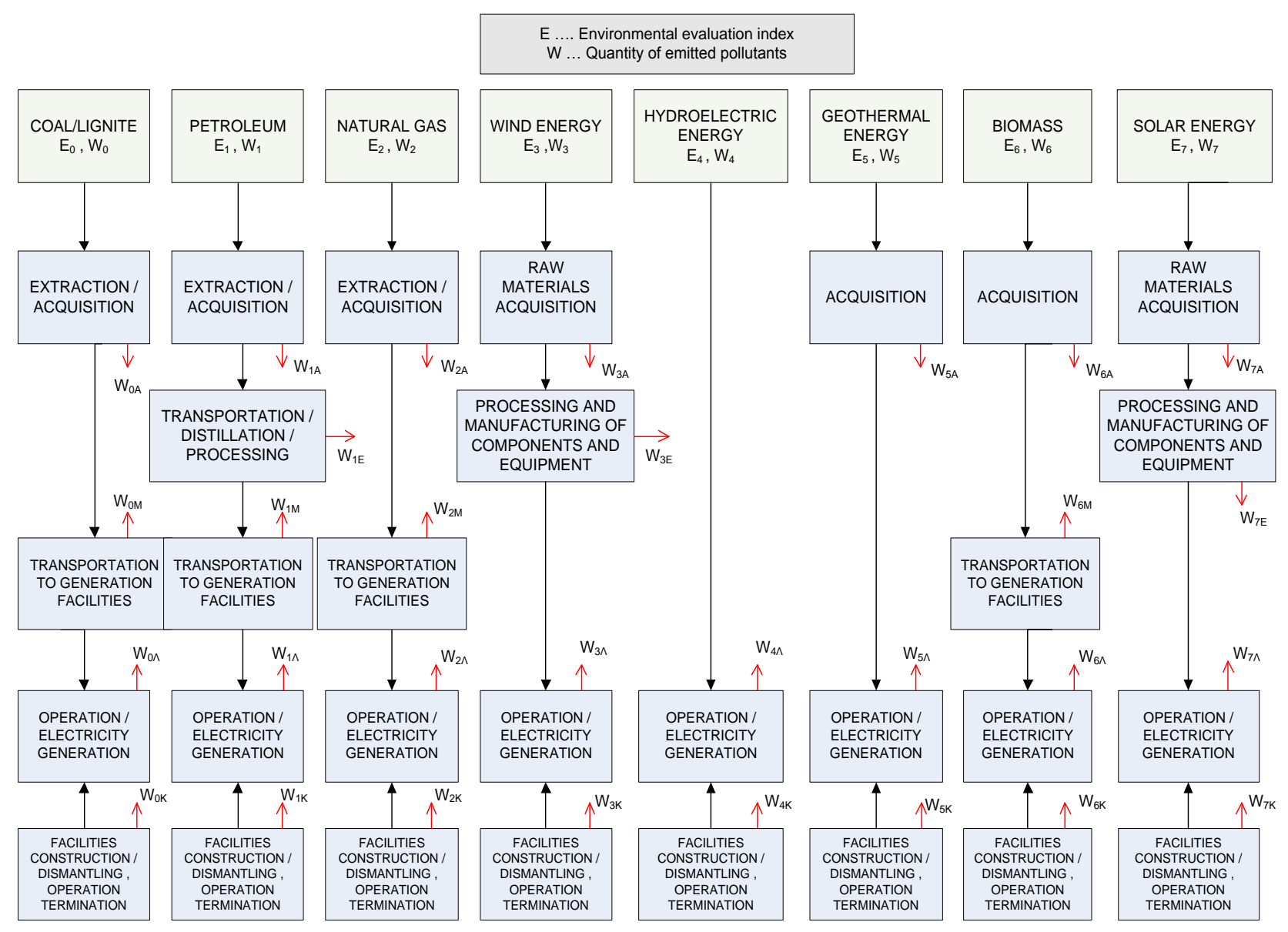

Fig.7. Life cycle stages for different energy sources and technologies used for electricity, heat generation and emissions of each stage.

When the $E_{i}$ symbol refers to the environmental evaluation indices, either the total environmental evaluation indices of every energy system can be used, or the indices of every impact or damage category for every energy system (impacts and damage categories are defined in Eco-indicator method (Goedkoop et al., 2000). Figure 8 presents the procedure of acquiring environmental evaluation indices for energy systems and the association of emissions with the impacts and damage categories through the Eco-indicator 99 method (Goedkoop \& Spriensma, 2001).

The objective functions that have been proposed must be modified accordingly if the environmental evaluation indices of the impacts or damage categories are used, and if more than one impacts or damage categories are examined at the same time. Table 2 presents a list of symbols for the environmental evaluation indices of the impact or damage categories. The set of equations that determine the proposed model follow. 
Mathematical equations of the optimization model

Objective functions of cost:

$$
\begin{aligned}
& \mathrm{Z}_{1}=\sum_{\mathrm{i}}^{\mathrm{n}} P_{i} * C_{i}, i=0,1,2 \ldots n \\
& \mathrm{Z}_{3}=\sum_{1}^{\mathrm{k}} Q_{l} * F_{l}, l=0,1,2 \ldots k \\
& \mathrm{Z}_{1}=\sum_{\mathrm{i}}^{\mathrm{n}} P_{i} *\left(C_{i}+K_{i}\right), i=0,1,2 \ldots n \\
& \mathrm{Z}_{4}=\sum_{1}^{\mathrm{k}} Q_{l} *\left(F_{l}+K_{l}\right), l=0,1,2 \ldots k
\end{aligned}
$$

Objective functions of environmental impacts:

$$
\begin{aligned}
& \mathrm{Z}_{2}=\sum_{\mathrm{i}}^{\mathrm{n}} P_{i} * E_{i}, i=0,1,2 \ldots n \\
& \mathrm{Z}_{5}=\sum_{1}^{\mathrm{k}} Q_{l} * E_{l}, l=0,1,2 \ldots k
\end{aligned}
$$

Note: The functions' indices $\left(Z_{1}, Z_{2}, \ldots\right)$ are referring to the number of equations and do not correspond to an energy source or technology like in the restrictions.

Restrictions:

- Electricity demand / generation

$$
\sum_{i}^{n} P_{i} \geq D_{1}, i=0,1,2 \ldots n
$$

- Heat demand / generation

$$
\sum_{l}^{k} Q_{l} \geq D_{2}, l=0,1,2 \ldots k
$$

- Maximum electricity and heat generation capacity

$$
\begin{aligned}
& \sum_{l}^{k} \sum_{i}^{n}\left(P_{i}+Q_{l}\right) \leq M \\
& \left\{P_{i} \leq M_{i}, Q_{l} \leq M_{l} \quad, i=0,1,2 \ldots n, l=0,1,2 \ldots k\right. \\
& \left\{\begin{array}{l}
P_{1} \leq M_{1}, Q_{1} \leq M_{1} \\
P_{2} \leq M_{2}, Q_{2} \leq M_{2} \\
\cdots \cdots \\
\cdots \cdots \\
P_{n} \leq M_{n}, Q_{k} \leq M_{k}
\end{array}\right.
\end{aligned}
$$


- Use percentage of RES (if applicable)

$$
\sum_{i}^{m} P_{i}+\sum_{l}^{m} Q_{l} \geq L, i=0,1,2 \ldots m, l=0,1,2 \ldots m
$$

- Environmental impacts (if applicable)

$$
\sum_{i}^{n} P_{i} * E_{i}+\sum_{1}^{\mathrm{k}} Q_{l} * E_{l} \leq B, i=0,1,2 \ldots n, l=0,1,2 \ldots k
$$

- Reliability

$$
\sum_{i}^{n} \frac{1}{R_{i}} P_{i}+\sum_{l}^{k} \frac{1}{R_{l}} Q_{l} \leq M, i=0,1,2 \ldots n, l=0,1,2 \ldots k
$$

- Social acceptance

$$
\sum_{i}^{n} P_{i} * S_{i}+\sum_{l}^{k} Q_{l} * S_{l} \leq D, i=0,1,2 \ldots n
$$

Additional details on the previous set of equations are provided in Appendix.

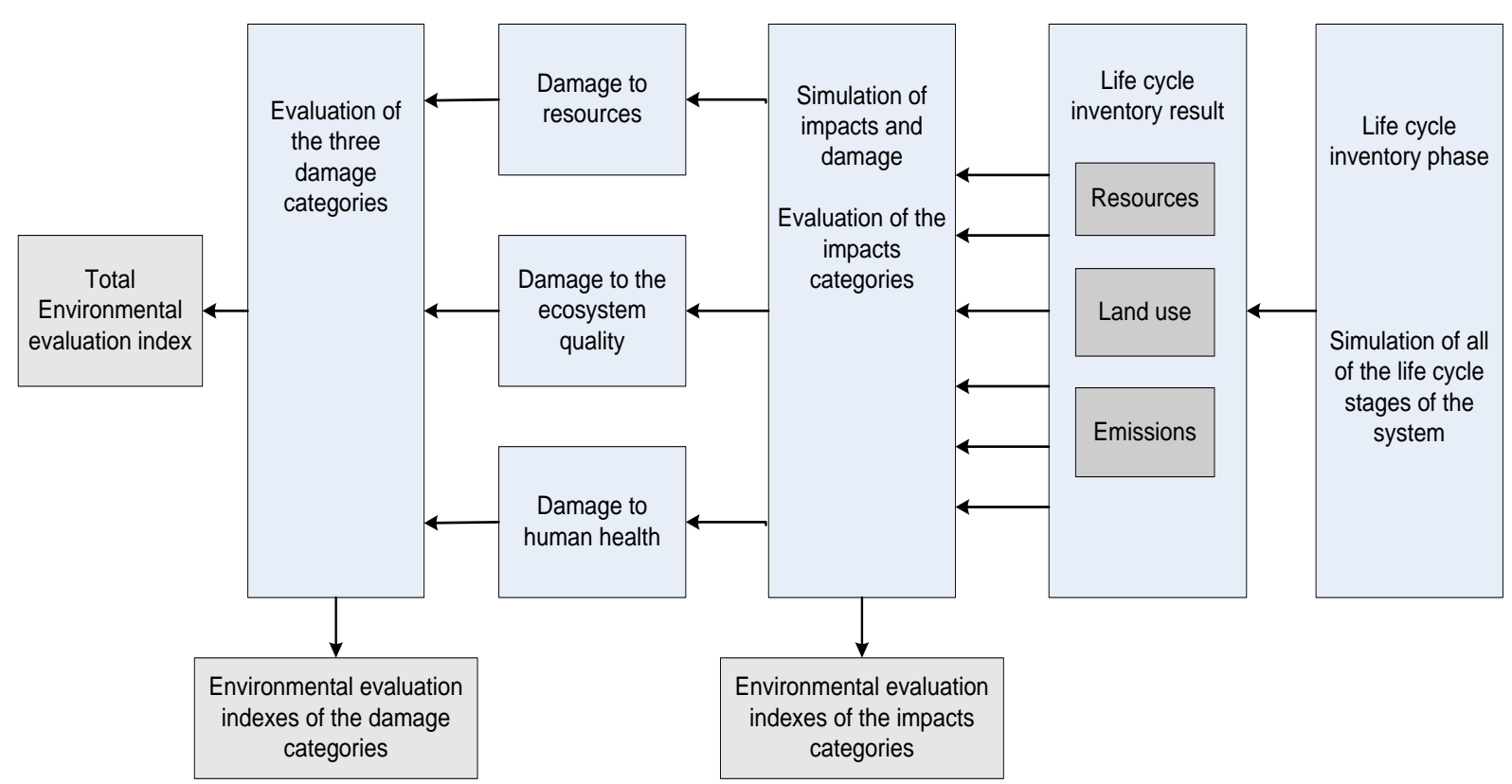

Fig.8. General procedure of acquiring environmental evaluation indices using Eco-Indicator 99 methodology (Goedkoop et al., 2000; Goedkoop \& Spriensma, 2001).

The selection of impact or damage related environmental evaluation indices, instead of the total indices is advisable when there is contribution of some pollutants to a specific impact or damage category. When the environmental evaluation indices of the impacts categories are used, the $E_{i}$ symbol is modified as follows:

$E_{i j}, \quad \mathrm{i}=0,1,2,3 \ldots \mathrm{n}$, where i represents the energy systems

$\mathrm{j}=1,2,3 \ldots \ldots \mathrm{n}$, where $\mathrm{j}$ represents the impact categories 
When the environmental evaluation indices of the damage categories are used, the $E_{\mathrm{i}}$ symbol is modified as follows:

$E_{i j}, \quad \mathrm{i}=0,1,2,3 \ldots \mathrm{n}$, where i represents the energy systems

$\mathrm{j}=1,2,3$, where $\mathrm{j}$ represents the damage categories

Table 2

Impact and Damage categories EcoIndicator 99 for the environmental evaluation indices applied.

\begin{tabular}{|c|c|c|c|c|c|c|c|c|}
\hline \multirow[b]{2}{*}{ Impact category } & \multicolumn{8}{|c|}{ Environmental evaluation indices } \\
\hline & $\begin{array}{l}\text { Coal / } \\
\text { Lignite }\end{array}$ & Petroleum & $\begin{array}{l}\text { Natural } \\
\text { gas }\end{array}$ & $\begin{array}{l}\text { Wind } \\
\text { energy }\end{array}$ & $\begin{array}{l}\text { Hydro- } \\
\text { power }\end{array}$ & $\begin{array}{l}\text { Geothermal } \\
\text { energy }\end{array}$ & Biomass & $\begin{array}{l}\text { Solar } \\
\text { energy }\end{array}$ \\
\hline Carcinogenic effects humans & $\mathrm{E}_{01}$ & $E_{11}$ & $E_{21}$ & $E_{31}$ & $E_{41}$ & $\mathrm{E}_{51}$ & $\mathrm{E}_{61}$ & $\mathrm{E}_{71}$ \\
\hline $\begin{array}{l}\text { Respiratory effects (inorganics) } \\
\text { on humans }\end{array}$ & $\mathrm{E}_{02}$ & $\mathrm{E}_{12}$ & $\mathrm{E}_{22}$ & $\mathrm{E}_{32}$ & $\mathrm{E}_{42}$ & $\mathrm{E}_{52}$ & $\mathrm{E}_{62}$ & $\mathrm{E}_{72}$ \\
\hline $\begin{array}{l}\text { Respiratory effects (organics) } \\
\text { on humans }\end{array}$ & $\mathrm{E}_{03}$ & $E_{13}$ & $\mathrm{E}_{23}$ & $\mathrm{E}_{33}$ & $\mathrm{E}_{43}$ & $\mathrm{E}_{53}$ & $\mathrm{E}_{63}$ & $\mathrm{E}_{73}$ \\
\hline $\begin{array}{l}\text { Human Health Damages due to } \\
\text { Climate Change }\end{array}$ & $\mathrm{E}_{04}$ & $\mathrm{E}_{14}$ & $\mathrm{E}_{24}$ & $\mathrm{E}_{34}$ & $\mathrm{E}_{44}$ & $\mathrm{E}_{54}$ & $\mathrm{E}_{64}$ & $\mathrm{E}_{74}$ \\
\hline $\begin{array}{l}\text { Human Health effects by Ionizing } \\
\text { Radiation }\end{array}$ & $\mathrm{E}_{05}$ & $\mathrm{E}_{15}$ & $\mathrm{E}_{25}$ & $\mathrm{E}_{35}$ & $\mathrm{E}_{45}$ & $\mathrm{E}_{55}$ & $\mathrm{E}_{65}$ & $\mathrm{E}_{75}$ \\
\hline $\begin{array}{l}\text { Human Health effects Ozone } \\
\text { Layer Depletion }\end{array}$ & $\mathrm{E}_{06}$ & $E_{16}$ & $\mathrm{E}_{26}$ & $\mathrm{E}_{36}$ & $\mathrm{E}_{46}$ & $\mathrm{E}_{56}$ & $\mathrm{E}_{66}$ & $\mathrm{E}_{76}$ \\
\hline $\begin{array}{l}\text { Damage Ecosystem Quality by } \\
\text { Ecotoxic Emissions }\end{array}$ & $\mathrm{E}_{07}$ & $\mathrm{E}_{17}$ & $\mathrm{E}_{27}$ & $\mathrm{E}_{37}$ & $\mathrm{E}_{47}$ & $\mathrm{E}_{57}$ & $\mathrm{E}_{67}$ & $\mathrm{E}_{77}$ \\
\hline $\begin{array}{l}\text { Damage Ecosystem Quality by } \\
\text { Acidification / Eutrophication }\end{array}$ & $\mathrm{E}_{08}$ & $\mathrm{E}_{18}$ & $\mathrm{E}_{28}$ & $\mathrm{E}_{38}$ & $\mathrm{E}_{48}$ & $\mathrm{E}_{58}$ & $\mathrm{E}_{68}$ & $\mathrm{E}_{78}$ \\
\hline $\begin{array}{c}\text { Damage Ecosystem Quality Land } \\
\text { Occupation \& Conversion }\end{array}$ & $\mathrm{E}_{09}$ & $\mathrm{E}_{19}$ & $\mathrm{E}_{29}$ & $\mathrm{E}_{39}$ & $\mathrm{E}_{49}$ & $\mathrm{E}_{59}$ & $\mathrm{E}_{69}$ & $\mathrm{E}_{79}$ \\
\hline $\begin{array}{c}\text { Damage Resources by extraction } \\
\text { of Minerals }\end{array}$ & $\mathrm{E}_{010}$ & $\mathrm{E}_{110}$ & $\mathrm{E}_{210}$ & $\mathrm{E}_{310}$ & $\mathrm{E}_{410}$ & $\mathrm{E}_{510}$ & $\mathrm{E}_{610}$ & $\mathrm{E}_{710}$ \\
\hline $\begin{array}{c}\text { Damage Resources by extraction } \\
\text { of Fossil Fuels }\end{array}$ & $\mathrm{E}_{011}$ & $\mathrm{E}_{111}$ & $\mathrm{E}_{211}$ & $\mathrm{E}_{311}$ & $\mathrm{E}_{411}$ & $\mathrm{E}_{511}$ & $\mathrm{E}_{611}$ & $\mathrm{E}_{711}$ \\
\hline $\begin{array}{c}\text { TOTAL } \\
\end{array}$ & $\mathrm{E}_{0}$ & $\mathrm{E}_{1}$ & $\mathrm{E}_{2}$ & $\mathrm{E}_{3}$ & $\mathrm{E}_{4}$ & $\mathrm{E}_{5}$ & $\mathrm{E}_{6}$ & $\mathrm{E}_{7}$ \\
\hline Damage Category & $\begin{array}{l}\text { Coal / } \\
\text { Lignite }\end{array}$ & Petroleum & $\begin{array}{l}\text { Natural } \\
\text { gas }\end{array}$ & $\begin{array}{l}\text { Wind } \\
\text { energy }\end{array}$ & $\begin{array}{l}\text { Hydro- } \\
\text { power }\end{array}$ & $\begin{array}{c}\text { Geothermal } \\
\text { energy }\end{array}$ & Biomass & $\begin{array}{r}\text { Solar } \\
\text { energy }\end{array}$ \\
\hline Human Health & $\mathrm{E}_{01}$ & $\mathrm{E}_{11}$ & $\mathrm{E}_{21}$ & $\mathrm{E}_{31}$ & $\mathrm{E}_{41}$ & $\mathrm{E}_{51}$ & $\mathrm{E}_{61}$ & $\mathrm{E}_{71}$ \\
\hline Ecosystem Quality & $\mathrm{E}_{02}$ & $\mathrm{E}_{12}$ & $\mathrm{E}_{22}$ & $E_{32}$ & $\mathrm{E}_{42}$ & $\mathrm{E}_{52}$ & $\mathrm{E}_{62}$ & $\mathrm{E}_{72}$ \\
\hline Resources & $\mathrm{E}_{03}$ & $\mathrm{E}_{13}$ & $\mathrm{E}_{23}$ & $\mathrm{E}_{33}$ & $\mathrm{E}_{43}$ & $\mathrm{E}_{53}$ & $\mathrm{E}_{63}$ & $\mathrm{E}_{73}$ \\
\hline $\begin{array}{l}\text { TOTAL ENVIRONMENTAL } \\
\text { EVALUATION INDEX }\end{array}$ & $\mathrm{E}_{0}$ & $\mathrm{E}_{1}$ & $\mathrm{E}_{2}$ & $\mathrm{E}_{3}$ & $\mathrm{E}_{4}$ & $\mathrm{E}_{5}$ & $\mathrm{E}_{6}$ & $\mathrm{E}_{7}$ \\
\hline
\end{tabular}

\subsection{Case study}

At this point an application of the multi-criteria optimization model for the island of Rhodes is presented. Rhodes covers an area of $1,407.9 \mathrm{~km}^{2}$ (544 sq. mi) with a total population of 115,490 inhabitants (Hellenic Statistical Authority, 2013). The existing interconnected power system of Rhodes - Chalki produces a total of 716,169,409 kWh, of which $676,780,091 \mathrm{kWh}$ by an autonomous conventional power station (APS) and $39,389,318 \mathrm{kWh}$ by RES, mainly using solar water heating collectors and a small wind park. Wind energy has been confirmed to have a great potential in South Aegean region and particularly in Rhodes (Center of Renewable Energy Sources, 2013b), as it is shown in Fig. 9. In more detail, the energy potential of Rhodes is considered to be very high in renewable energy sources with an estimated wind energy potential of $246 \mathrm{MW}$ and $1.6 \times 10^{11} \mathrm{kWh} / \mathrm{y}$ of solar energy potential (Oikonomou et al., 2009; Koroneos et al., 2005; Kaldellis, 2004). As of today, there is a small-size wind park constructed in Rhodes with a total power of $3 \mathrm{MW}$ (5 W/T of 
$600 \mathrm{~kW}$ ), which is planned to expand up to $31 \mathrm{MW}$, and a second one that is currently under construction with a total projected power of 18 MW (The Wind Power, 2013).

As far as solar energy is concerned, there are broadly two available types for power generation, namely photovoltaic parks and solar thermal power plants. A third solution for saving electricity is extensive use of solar water heating collectors, which is appropriate for tourism destinations, e.g. island of Rhodes (Daskalaki and Balaras, 2004; Li et al., 2007). In our case, there are already 53,725 $\mathrm{m}^{2}$ of solar collectors installed in Rhodes, on the roofs of hotels and residences, thus heating water without consumption of electricity. On the other hand, parallel installations of wind parks and photovoltaics on an island surface would probably cause disturbance to the local environment (Katsaprakakis, 2012; Cavallaro and Ciraolo, 2005).

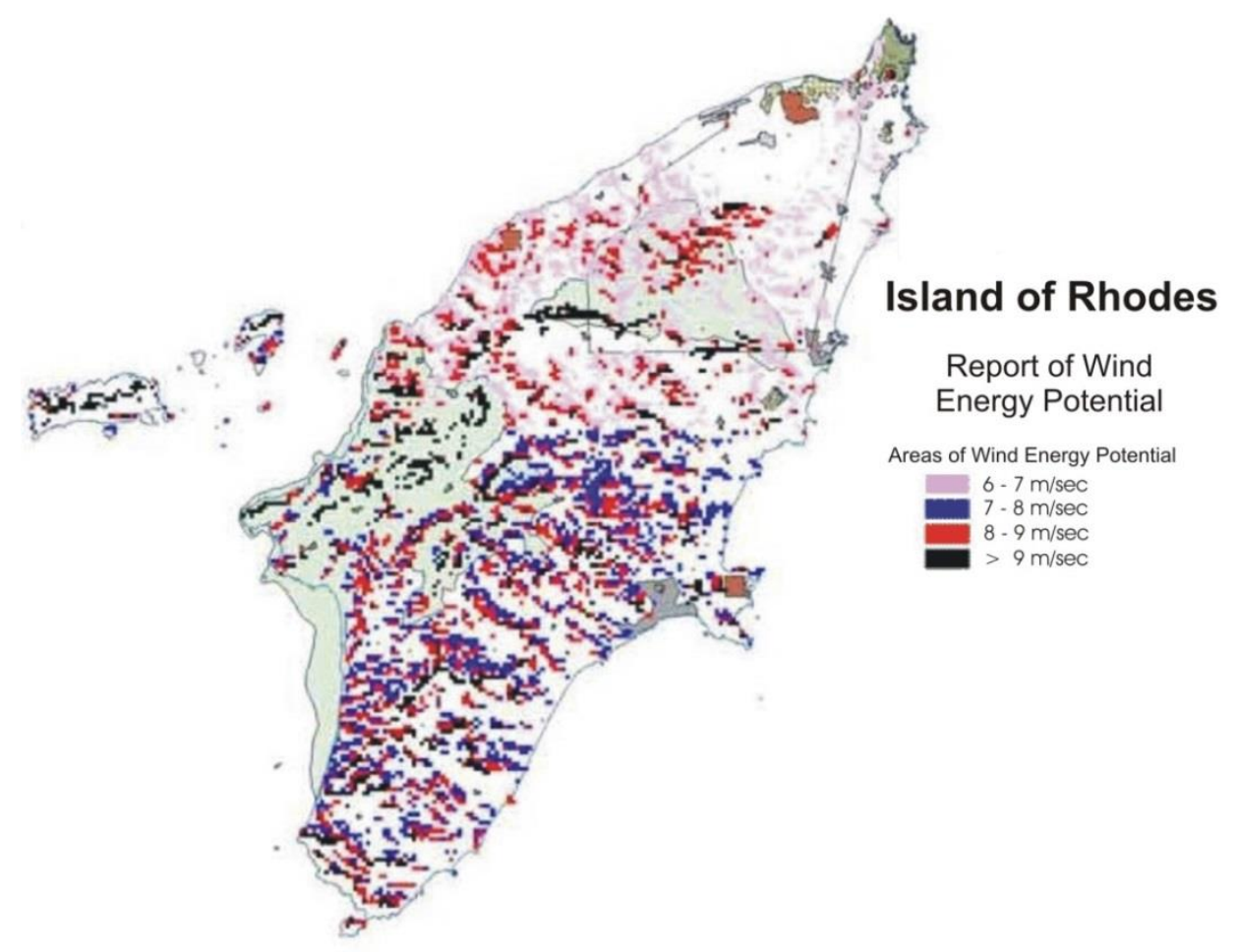

Fig. 9. Map of wind energy potential areas for the island of Rhodes (Center of Renewable Energy Sources, 2013b).

Another interesting renewable source is geothermal energy. The geothermal field of Nisyros island will probably provide electricity to small islands around and Nisyros itself, through a geothermal power plant of $10 \mathrm{MW}$ in the years to come (a 5MW project has already begun) (Geothermal Electricity, 2013). It would not be advisable to transfer power with a submarine cable from Nisyros geothermal power plant to Rhodes, especially for such a limited power installed, mainly due to the 130 $\mathrm{km}$ distance in-between and corresponding investment. Therefore, the proposed scenario of an alternative power system for the island of Rhodes will include large wind parks and installation of extra solar water heating collectors, apart from the operation of APS that ensures stability of the system. 
The electricity generation financial cost, $C_{i}$, for each system $i$ under consideration as a function of time $X_{i}$ in years, consists of a fixed cost, $C_{f}$, and a cost that varies with the energy amount produced by the source, $C_{\text {var }}$, i.e.:

$$
C_{i}=C_{f}+C_{\text {var }} \cdot X_{i}
$$

The cost of power generation by the autonomous power station, $C_{l}$, is a function of fixed production cost, $C_{11}$, and the variable cost, $C_{12}$, associated with the fuel cost. According to Public Power Corporation of Greece (2013), the cost for operating APS-Rhodes is:

$$
C_{1}=27,467,862+0.192 \cdot X_{1}
$$

The cost for the wind park depends on the type of the wind turbines that will be installed. According to Fingersh et al. (2006), the cost of a wind turbine, $C_{3}$ in $€$ /year, comprised by the fixed cost of purchase, transfer, installation and the cost of operation and maintenance, is given as:

$$
C_{3}=C_{3 f}+C_{3 o p \& m} \cdot X_{3}
$$

The fixed cost of a wind turbine is expressed as a function of the machine diameter $D$ (Burton et al., 2001):

$$
C_{3 f}=C_{T}(60) \cdot\left(0.72\left(\frac{D}{60}\right)^{3}+0.1422\left(\frac{D}{60}\right)^{2}+0.1378\right)
$$

,where $C_{T}(60)$ is the total cost for a $1.5 \mathrm{MW}, 60$ meter diameter wind turbine (baseline machine). The total cost per $\mathrm{kW}$ typically varies from approximately $900 € / \mathrm{kW}$ to $1,150 € / \mathrm{kW}$, depending on the manufacturer (The European Wind Energy Association, 2014). Therefore, the fixed cost, including drive train, nacelle, control, safety system, condition monitoring, foundations, transportation, roads \& civil work, assembly \& installation, electrical interface-connections, engineering and permits, for a 1.5 MW wind turbine totals about $1,500,000 €$.

Moreover, the variable costs associated with operation and maintenance have been assessed by Fingersh et al. (2006) for various types of wind turbines and Table 3 provides representative data in $€ /$ year for $600 \mathrm{~kW}, 1.5 \mathrm{MW}$ and $3 \mathrm{MW}$ turbines.

Considering a triple active inox type-solar water heating collector system with a $200 \mathrm{lt}$ tank, $4 \mathrm{~m}^{2}$ collectors' total surface and 20 years life span for the collectors, the cost of purchase, installation and operation, $C_{7}$, in $€ /$ year is given by (Koroneos and Nanaki, 2012; Koroneos et al., 2005):

$$
C_{7}=1,475+9,250 \cdot X_{7}
$$

Transportation services of APS are fueled by conventional energy sources based on petroleum, and it is assumed that the cost of use of conventional fuels by fuel trucks is included in final fuel costs to the power producer. On the other hand, wind turbines (W/T), inverters, batteries and foundations are imported from Germany to Greece assuming road transport covering a $1,650 \mathrm{~km}$ distance by a 40 tonnes truck. Solar collectors and auxiliary equipment are manufactured in Greece. All W/T-system components and solar collectors will be transshipped to a freighter travelling $635 \mathrm{~km}$ from port of Piraeus to the island of Rhodes, where the assembly procedures of the systems take place. Cost for 
delivering equipment from one port to the other by cargo ship using 40FT containers is $288 €$ per container (Sea Freight, 2013).

Table 3

Operation and Maintenance costs for various types of wind turbines (Fingersh et al., 2006).

\begin{tabular}{cc}
\hline W/T nominal power & $\boldsymbol{C}_{3 \text { sop } m}(\boldsymbol{€} / \mathbf{y})$ \\
\hline 600 & 46,800 \\
1500 & 99,400 \\
3000 & 196,000 \\
\hline
\end{tabular}

The energy needs in the island of Rhodes are the sum of the electricity consumption (Fig. 10) and the consumption of energy for hot water. Concerning the wind power potential, it is assumed that up to 150 land based-wind turbines could be possibly installed on the island of Rhodes. For the solar energy, it is assumed that the solar collectors can cover an area of $3 \%$ maximum, which is not considered to be excessive due to the fact that most of the solar water heating systems are roofed on buildings. With the previous limitations social acceptance of $\mathrm{W} / \mathrm{T}$ and $\mathrm{SWH}$ installations should be achieved. The efficiency of the solar water heaters is about $15 \%$ and as far as concerns the power produced by the wind turbines, it is assumed that $15 \%$ of it is lost. Renewable energy sources, such as wind turbines and solar collectors, have been reported to produce zero emissions during power generation and low emissions when considering their whole life cycle (Theodosiou et al., 2014; Evans et al., 2009).

Next, the results from the implementation of the proposed multi-criteria optimization model for the case of Rhodes are presented and a benchmarking report of the associated environmental impacts between the existing and the optimized power system is provided.

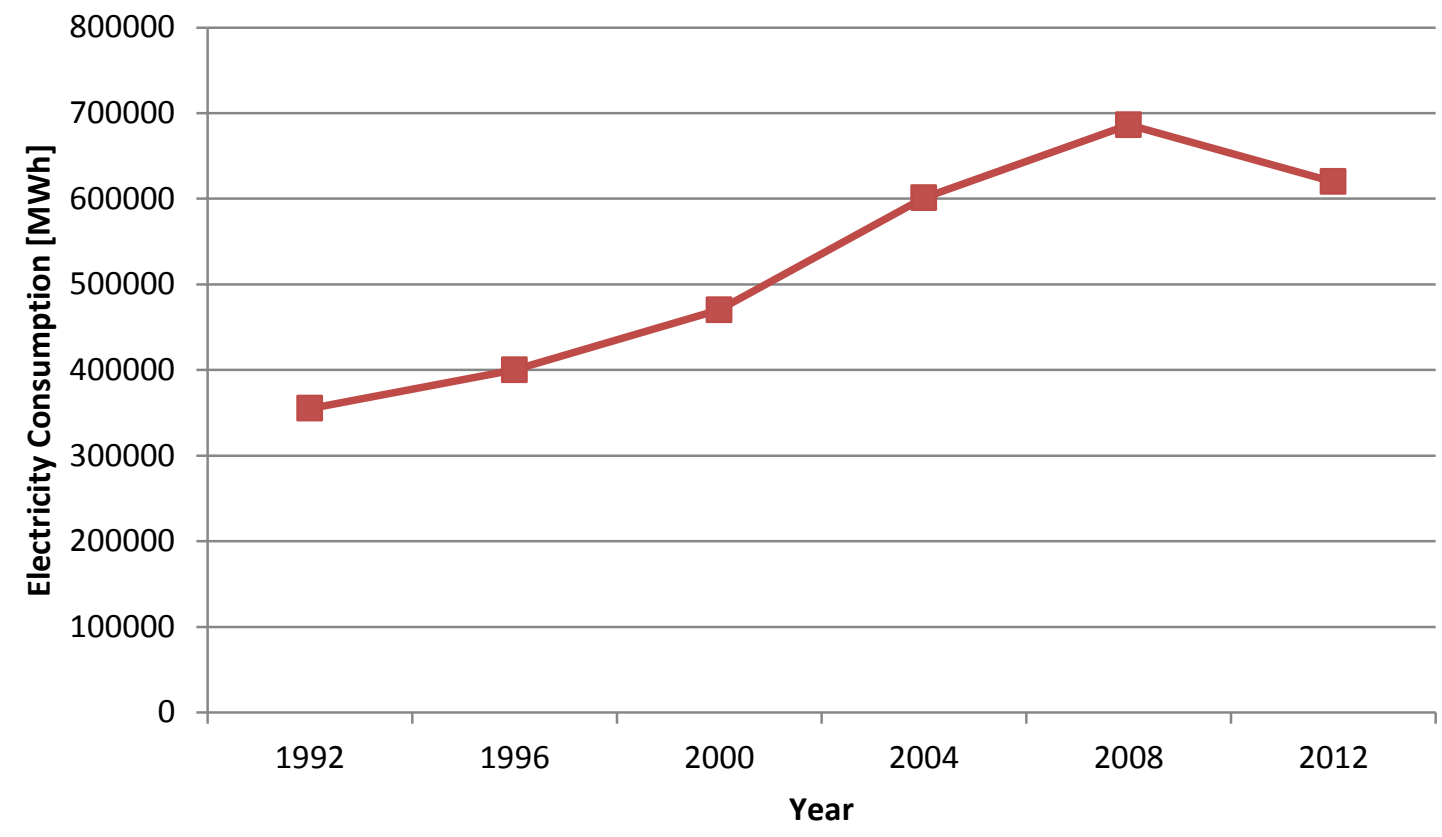

Fig. 10. Consumption of electricity in the island of Rhodes. 


\section{Results}

The existing power production system of Rhodes is comprised by an APS that produces the vast majority of power needed supplemented by extensive use of solar water heating systems and a small wind park. Table 4 shows the capacity and energy sources of the power system of Rhodes in 2012.

After the mathematical solution of the proposed multi-criteria model took place, a new power system emerged with 35 wind turbines (W/T) of $600 \mathrm{~kW}$ and 69 turbines with a nominal power of 3 MW. In addition, solar water heating collectors are proposed in excess of those already installed, thus finally amounting $57,346 \mathrm{~m}^{2}$. Finally, power generation from the APS burning heavy fuel oil is reduced to a percentage that is critical for the balance of the power system, as shown on Table 5. The optimal participation of the three energy sources in the electricity system of Rhodes is depicted in Fig. 11, where it appears that energy from renewables would in total surpass the corresponding from nonrenewables, if this case scenario would be implemented.

Table 4

Existing participation of energy sources to the power production system of Rhodes (year 2012).

\begin{tabular}{lcc}
\multicolumn{1}{c}{ Energy Source } & Power produced (kWh) & $\begin{array}{c}\text { Installed Power and Number of } \\
\text { Percentage of } \\
\text { participation }\end{array}$ \\
\hline Autonomous power station (APS) & $676,780,091$ & 1 APS, $206 \mathrm{MW}$, Heavy Fuel Oil \\
Wind power & $5,841,903$ & 5 W/T of $600 \mathrm{~kW}$ \\
Solar energy & $33,547,415$ & $53,725 \mathrm{~m}^{2}$ \\
Total & $716,169,409$ & - \\
\hline
\end{tabular}

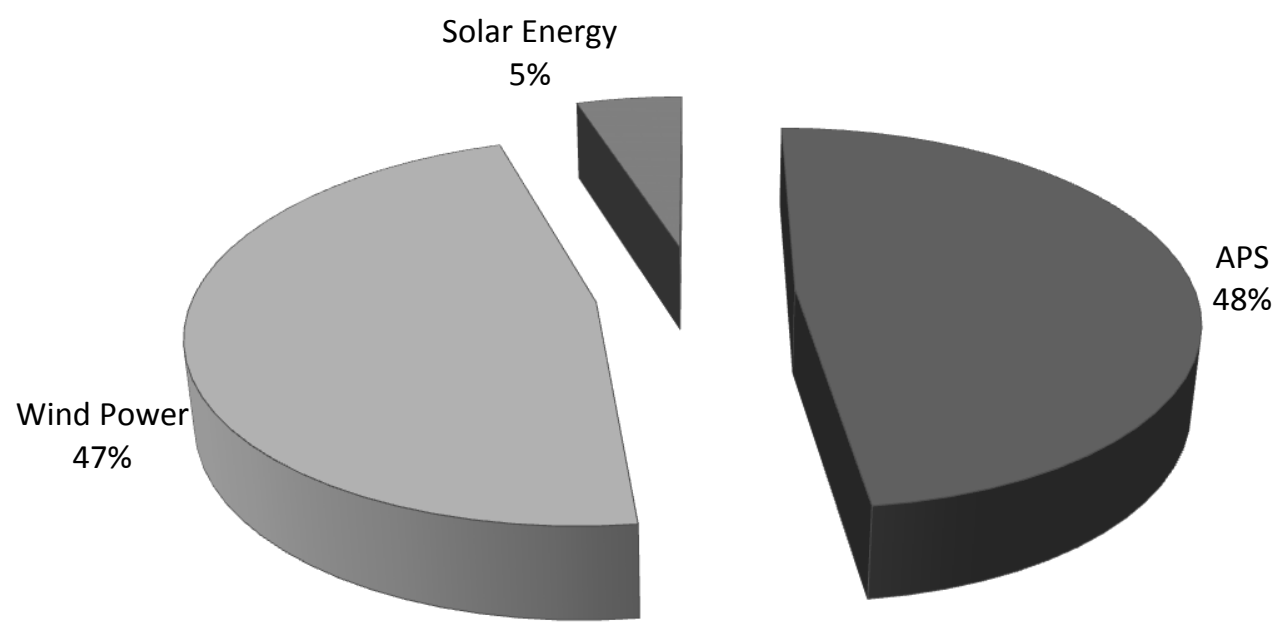

Fig. 11. Optimal participation of each energy source for Rhodes case scenario. 
Concerning the environmental aspect of the solution, life cycle assessment has been applied in order to identify and quantify the environmental performance of the existing and the proposed optimized power systems. For this reason Eco-Indicator 99 tool was chosen as being reliable and practical (Wursthorn et al., 2011; Blengini, 2008) for determining the impact categories, categorization, normalization and finally weighted damage report. The hierarchist version of EcoIndicator 99 and the weighting set of H/A resulted in the damage scores related to the eleven impact categories that correspond to the existing power system of the island and the optimized solution, as shown on Tables 6 and 7. The results included in these tables present the impact during a 20-yearperiod that is typically considered as a good estimation of the life-span for the renewable energy systems (Ardakani et al., 2010) the last column on Tables 6 and 7 provide the weighted damage scores per $\mathrm{kWh}$ produced by the power systems for the assumed useful life of 20 years. As it is clearly depicted in Fig. 12 there would be a large reduction in the damages caused by the existing power system, if the optimized solution were put in use.

Table 5

Optimal participation of energy sources to the power production system for the Rhodes case scenario.

\begin{tabular}{lccc}
\hline \multicolumn{1}{c}{ Energy Source } & Power produced $(\mathbf{k W h})$ & $\begin{array}{c}\text { Installed Power and Number of } \\
\text { APS, W/T or Solar Collectors }\end{array}$ & $\begin{array}{c}\text { Percentage of } \\
\text { participation }\end{array}$ \\
\hline Autonomous power station (APS) & $343,761,316$ & $1 \mathrm{APS}, 206 \mathrm{MW}$, Heavy Fuel Oil & 48 \\
Wind power & $336,599,622$ & $35 \mathrm{~W} / \mathrm{T}$ of $3000 \mathrm{~kW}, 69 \mathrm{~W} / \mathrm{T}$ of & 47 \\
& & $600 \mathrm{~kW}$ & 5 \\
Solar energy & $35,808,471$ & $57,346 \mathrm{~m}^{2}\left(3621 \mathrm{~m}^{2} \mathrm{new}\right)$ & 100 \\
Total & $716,169,409$ & - & \\
\hline
\end{tabular}

In ten out of eleven impact categories the reported reduction in weighted damage per category ranges from $21.45 \%$ in minerals extraction to $49.01 \%$ in fossil fuels extraction. The only exception to the rule concerns carcinogenic effects, presenting a slight increase by $2.69 \%$ in the damage caused if a transition from the present system to the optimized would take place. Overall, the results support a wide improvement of the environmental profile of the power generation system in Rhodes, as it is further presented in Fig. 13. The cumulative damage assessment groups the eleven impact categories in three damage categories, namely Human Health, Ecosystem Quality and Resources. In Fig. 13 it is apparent that damage per $\mathrm{kWh}$ produced is shrunk across all three categories and the largest improvement concerns Resources extraction.

Table 6

Weighted environmental damage scores per impact category for the existing system in island of Rhodes (EI 99 H/A).

\begin{tabular}{lccr}
\hline Impact category & Unit & $\begin{array}{c}\text { Existing system* } \\
\text { Impact in 20 years }\end{array}$ & $\begin{array}{c}\text { Existing system* } \\
\text { per kWh power produced }\end{array}$ \\
\hline Carcinogenic effects & DALYs & $7.4621 \mathrm{E}+08$ & $5.2098 \mathrm{E}-02$ \\
Respiratory Inorganics & DALYs & $7.4285 \mathrm{E}+08$ & $5.1863 \mathrm{E}-02$ \\
Respiratory Organics & DALYs & $2.4802 \mathrm{E}+05$ & $1.7316 \mathrm{E}-05$
\end{tabular}




\begin{tabular}{lccc}
\hline Climate Change & DALYs & $4.5786 \mathrm{E}+08$ & $3.1966 \mathrm{E}-02$ \\
Ionizing Radiation & DALYs & $1.5135 \mathrm{E}+05$ & $1.0567 \mathrm{E}-05$ \\
Ozone Layer Depletion & DALYs & $7.8299 \mathrm{E}+04$ & $5.4665 \mathrm{E}-06$ \\
Ecotoxic emissions & $\mathrm{PDF} \times \mathrm{m}^{2} \times \mathrm{yr}$ & $1.1937 \mathrm{E}+09$ & $8.3342 \mathrm{E}-02$ \\
Acidification / Eutrophication & $\mathrm{PDF} \times \mathrm{m}^{2} \times \mathrm{yr}$ & $1.2039 \mathrm{E}+08$ & $8.4054 \mathrm{E}-03$ \\
Land Use & $\mathrm{PDF} \times \mathrm{m}^{2} \times \mathrm{yr}$ & $1.0978 \mathrm{E}+07$ & $7.6641 \mathrm{E}-04$ \\
Minerals Extraction & MJ surplus energy & $8.8574 \mathrm{E}+05$ & $6.1839 \mathrm{E}-05$ \\
Fossil Fuels Extraction & MJ surplus energy & $2.0590 \mathrm{E}+09$ & $1.4375 \mathrm{E}-01$ \\
\hline
\end{tabular}

Existing system $=94.5 \%$ APS power plus $5.5 \%$ Renewables

Table 7

Weighted environmental damage scores per impact category for the system resulting after optimization takes place (EI 99 H/A).

\begin{tabular}{lccc}
\hline Impact category & Unit & $\begin{array}{c}\text { OPS } \\
\text { Impact in 20 years }\end{array}$ & $\begin{array}{c}\text { OPS* } \\
\text { per kWh power produced }\end{array}$ \\
\hline Carcinogenic effects & DALYs & $7.6629 \mathrm{E}+08$ & $5.3499 \mathrm{E}-02$ \\
Respiratory Inorganics & DALYs & $3.8879 \mathrm{E}+08$ & $2.7143 \mathrm{E}-02$ \\
Respiratory Organics & DALYs & $1.3164 \mathrm{E}+05$ & $9.1905 \mathrm{E}-06$ \\
Climate Change & DALYs & $2.3558 \mathrm{E}+08$ & $1.6448 \mathrm{E}-02$ \\
Ionizing Radiation & DALYs & $8.3423 \mathrm{E}+04$ & $5.8243 \mathrm{E}-06$ \\
Ozone Layer Depletion & DALYs & $4.0553 \mathrm{E}+04$ & $2.8313 \mathrm{E}-06$ \\
Ecotoxic emissions & PDF $\times m^{2} \times y r$ & $7.7586 \mathrm{E}+08$ & $5.4167 \mathrm{E}-02$ \\
Acidification / Eutrophication & PDF $\times m^{2} \times y r$ & $6.1964 \mathrm{E}+07$ & $4.3261 \mathrm{E}-03$ \\
Land Use & PDF $\times m^{2} \times y r$ & $5.7587 \mathrm{E}+06$ & $4.0205 \mathrm{E}-04$ \\
Minerals Extraction & MJ surplus energy & $6.9577 \mathrm{E}+05$ & $4.8576 \mathrm{E}-05$ \\
Fossil Fuels Extraction & MJ surplus energy & $1.0500 \mathrm{E}+09$ & $7.3305 \mathrm{E}-02$ \\
\hline${ }^{+}$OPS = Optimized Power System, 48\% APS power, 47\% wind energy, 5\% solar energy &
\end{tabular}

${ }^{\dagger}$ OPS = Optimized Power System, 48\% APS power, 47\% wind energy, $5 \%$ solar energy 
Existing system $\quad$ O.P.S.

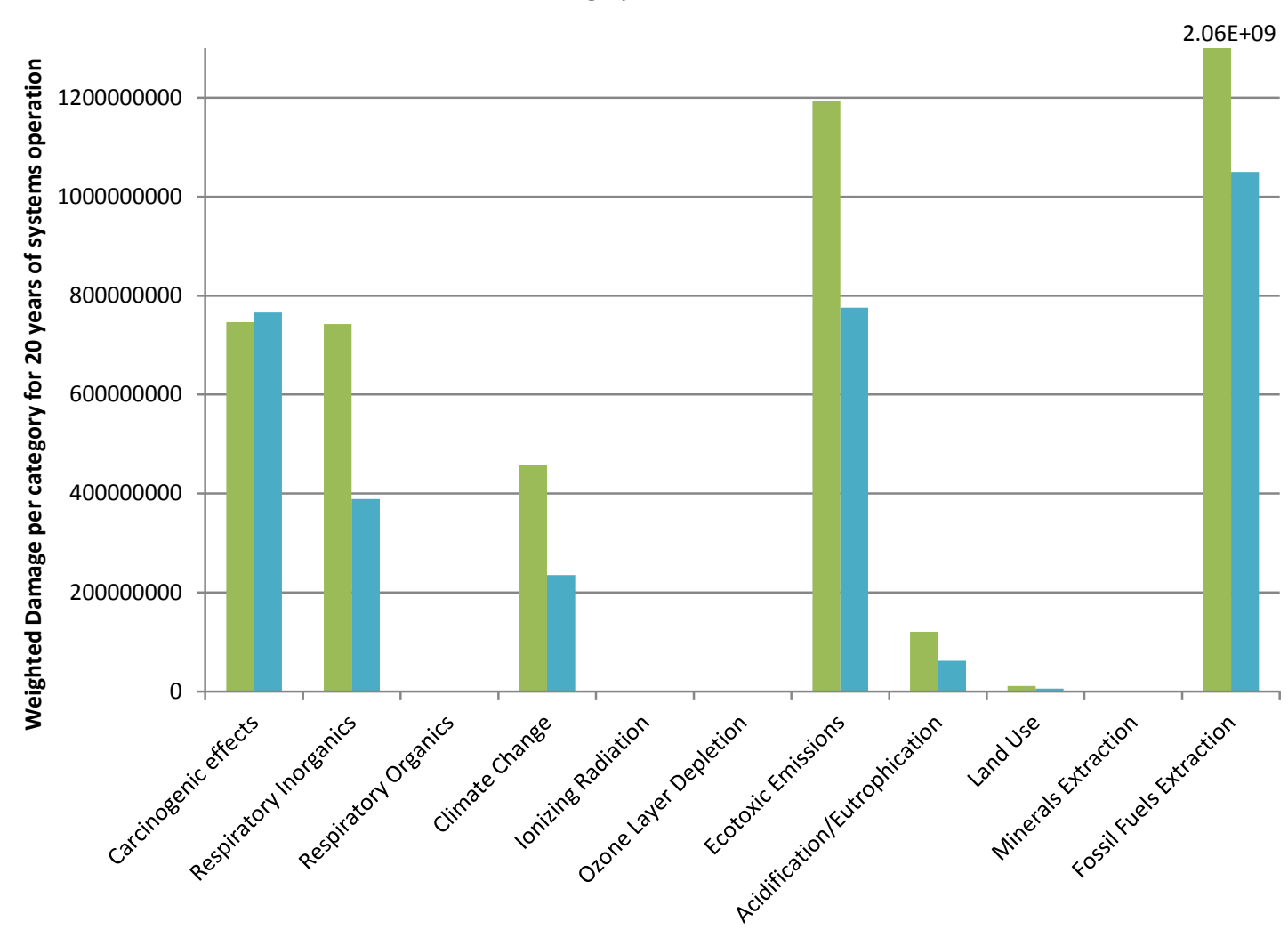

Fig. 12. Weighted environmental damage scores per impact category for the existing and proposed optimized power systems.

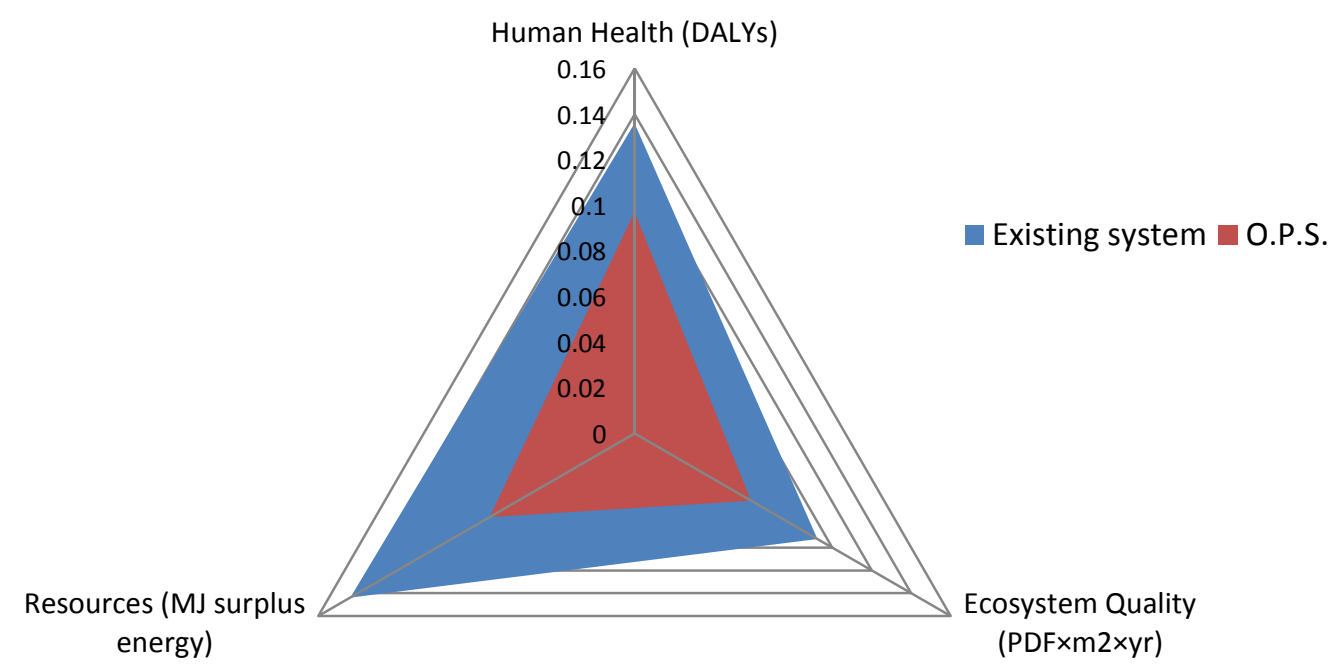

Fig. 13. Representation of Cumulative damage assessment per kWh of power produced for the existing and proposed optimized power systems. 


\section{Discussion}

In the published literature, there is a wealth of models concerning multi-criteria or multi-objective optimization for decision-making in energy applications, based on weighted sum, priority setting, outranking, and fuzzy set methodologies (San Cristóbal, 2011; Alarcon-Rodriguez et al., 2010; Ren et al., 2010; Wang et al., 2008; Kahraman, 2008; Løken, 2007; Cloquell-Ballester et al., 2007; Pohekar \& Ramachandran, 2004). As Wang et al. (2009) state, the need for new optimization techniques has arisen from the pressure of meeting multiple goals, as well as, the complexity of socio-economic and dynamic physical systems. The proposed multi-criteria optimization model aims to contribute in the field of energy systems design and environmental protection. The life cycle concept adopted in the model development ensures that a more holistic approach is followed in the design, while the use of environmental evaluation tools like LCA can help in integrating the environmental aspect in the conventional design. Previous work on the field of energy systems design was concentrated mainly on economic cost minimization while the environmental aspect in many cases was not included in the analysis (Lozano et al., 2010; Bernal-Agustín \& Dufo-López, 2009; Yang et al., 2009). In those cases that the environmental aspect was included in the preliminary design, this was done mainly in the form of restrictions with the relative data to include an input - output inventory analysis, i.e. the emissions were not associated with the environmental impacts. Due to the increasing concerns relating to the environmental pollution that derives mainly from anthropogenic activities, with the electricity generation sector comprising the most typical example, the efforts for finding measures and ways to minimize the environmental pollution problem at source are becoming more and more imperative.

An implementation of the proposed model for an island economy revealed its usefulness in finding an optimum solution from both a financial and an environmental point of view. The model supported a solution that increases participation of renewables in power generation, thus reducing damages to humans and the environment, while at the same time minimizing cost of operation and/or purchase, installation, electrical connections, engineering and permits. At the same other parameters such as social acceptance of wide installations of land-based renewable systems were taken into account in formulating the optimum solution. A balanced power system that ensures its viability and cost efficiency and at the same time satisfies the need for cleaner power generation has been proposed. Wind parks with an aggregate nominal power of 146,4 MW exploiting an estimated wind energy potential of $246 \mathrm{MW}$ on the island of Rhodes, as well as extended use of solar energy in the form of solar water heating systems are key contributors in changing to the better the profile of the existing power system. An LCA using the hierarchist version of Eco-Indicator 99 framework has shown that the proposed energy mix is advantageous from an environmental aspect comparatively to the existing power system, which is dominated by an APS burning heavy fuel oil. During the 20-year-period of operation, which will possibly be longer, the proposed system will definitely achieve an even larger improvement of the local environmental conditions, since the renewable systems are not manufactured on the island of Rhodes but transportation of all equipment either from Germany or continental Greece is involved. 


\section{Conclusions}

As particular knowledge generated in this paper, the environmental aspects of design and planning characteristics of energy systems are integrated with parameters such as financial cost, availability, capacity, location in a single optimization methodology. The concept has been formulated by including Life Cycle Analysis in the conventional optimization process. The implementation of our model creates energy mixes that overcome the problem of applying LCA or financial optimization on a unilateral basis; the proposed way for combining LCA with financial \& location-specific objectives in the minimization process of multi-criteria analysis produces environmentally balanced and cost efficient energy system solutions. The equality in managing the environmental and cost-related factors is the actual advantage of this specific model in comparison to others that have been previously published.

The produced theoretical framework that minimizes environmental damages along with energy related financial costs has been applied to an island economy. The multi-criteria analysis revealed an optimized participation of energy sources (i.e. heavy fuel oil, wind, solar) in the local energy mix. The implementation of that mix of energy carriers would cause a significant improvement for the local economy and environment, since energy from renewables would in total surpass the corresponding from non-renewables. Hence, the positive effects of that change in the energy mix of the island would greatly contribute to achieving environmental sustainability and economic viability at local level; it would, also, serve as a successful case for repetition to other islands or local territories.

As it is well known, there are national and EU policies that support sustainable energy mixes across EU member states through related energy policies, e.g. subsidies for constructing renewable energy projects. The proposed multi-criteria analysis model can probably prove useful for addressing energy related problems that are characterised by conflicting assessments and interests. In specific, it can serve as a useful tool for national authorities, policy makers and territorial decision making bodies for planning sustainable energy systems that incorporate multiple energy carriers.

Future development of the multi-criteria optimization model proposed in this paper should focus on examining the possibilities of including energy and exergy analysis in the model so that they are integrated and used together with the environmental evaluation (LCA). In addition to this, it would be of particular interest to investigate the way exergetic life cycle analysis (ELCA) could be used in the optimization model together or replacing LCA. Furthermore, a sensitivity analysis could be useful in order to examine the effects that various directives, legislations, strategies and policies have on the optimization model - and therefore on the energy systems design procedure - as well as, the effects of various incentives provided at a local, regional, national or international level.

\section{Appendix}

\section{General notes:}

i. In equations 11 and 13, the symbol $\mathrm{C}$ refers to the generation cost. The total cost may include the external cost and the cost of excess of the limitations of emissions allowances of electricity generation (symbol K). It is included here in order to provide a more global and complete 
view with respect to total impacts (environmental, social and financial) that are related with electricity generation; it constitutes a totally subjective estimation.

ii. The total cost is given in $€ / M W h$. In general, this cost is comprised of the capital/fixed cost $(€)$ and the operational cost $(€ / \mathrm{MWh})$. The conversion of the fixed cost in $€ / \mathrm{MWh}$ is performed based on a life span horizon for every system. Alternatively, equations $29-32$ can be used:

For fossil fuels:

$$
\begin{aligned}
& C_{i}=C_{1}+C_{2} * P_{i}+C_{3}, i=0,1,2 \ldots n \\
& C_{i}=C_{1}+C_{2} * Q_{i}+C_{3}, i=0,1,2 \ldots n
\end{aligned}
$$

Where: $C_{1}$ is the investment cost in $€, C_{2}$ is the cost of the fuel in $€ / M W h$ and $C_{3}$ is the cost of other expenses in $€$, or

$$
\begin{aligned}
& C_{i}=C_{1} * P_{i}+C_{2} * P_{i}, i=0,1,2 \ldots n \\
& C_{i}=C_{1} * Q_{i}+C_{2} * Q_{i}, i=0,1,2 \ldots n
\end{aligned}
$$

Where: $C_{1}$ is the investment cost and $C_{3}$ is the cost of other expenses in $€ / \mathrm{MWh}$ if a conversion in a life span horizon is performed and $C_{2}$ is the fuel cost in or $€ / \mathrm{MWh}$.

For RES similar equations can be used.

iii. Equation 13 can be used in case the designer wishes to include the external cost and the cost of excess of the limitations of emissions allowances of electricity generation in the analysis.

iv. In equation $15, E_{i}$ refers to the total environmental evaluation indices for every energy system or to the environmental evaluation indices of the impacts and damage categories when only one category is examined.

v. In the RES use percentage restriction, $L$ is determined by legislation or proposed EU's directives.

vi. The restriction that refers to the environmental impacts (eq. 21) is applicable when reference for specific pollutants is required, e.g. $\mathrm{CO}_{2}, \mathrm{SO}_{\mathrm{x}}$, etc. and there is a maximum allowed limit of emission $B$ that should not be exceeded.

vii. The reliability factor $R$ varies between $0-100 \%$ and is used to express the problems of the technological reliability that take place during the generation and transfer of energy as well as the fact that the RES do not constitute a permanent and constant energy source. Typical values of the reliability factor can be found in Mamlook et al. (2001).

viii. The social acceptance factor $S$ varies between 0 and $100 \%$, and it expresses the level of consent on behalf of the community, regarding the use of a specific energy system or energy source for a specific end use. In order to determine the social acceptance factor a statistical measurement instrument is usually used (e.g. self-administered questionnaires). 


\section{References}

Alarcon-Rodriguez, A., Ault, G., Galloway, S., 2010. Multi-objective planning of distributed energy resources: A review of the state-of-the-art. Renew. Sust. Energ. Rev. 14 (5), 1353-1366.

Albrecht, D., Bultena, G., Hoiberg, E., Nowak, P., 1982. Measuring environmental concern: The new environmental paradigm scale. J. Environ. Educ. 13 (3), 39-43.

Alexander B., Barton G., Petrie J., Romagnoli J., 2000. Process synthesis and optimisation tools for environmental design: methodology and structure. Comput. Chem. Eng. 24 (2-7), 1195-1200.

Andrews, J., Shabani, B., 2012. Re-envisioning the role of hydrogen in a sustainable energy economy. Int. J. Hydrogen Energ. 37 (2), 1184-1203.

Ardakani, F. J., Riahy, G., Abedi, M., 2010. Optimal sizing of a grid-connected hybrid system for northwest of Iran-case study, in Environment and Electrical Engineering (EEEIC), 2010 9th International Conference on, pp. 29-32.

Azapagic A., 1999. Life cycle assessment and its application to process selection, design and optimization. Chem. Eng. J. 73, 1-21.

Azapagic A., Clift R., 1999. Life cycle assessment and multiobjective optimisation. J. Clean. Prod. 7, 135143.

Azar, C., Lindgren, K., Andersson, B. A., 2003. Global energy scenarios meeting stringent $\mathrm{CO}_{2}$ constraints - cost-effective fuel choices in the transportation sector. Energ. Policy 31 (10), 961-976.

Baasel W.D., 1985. Economic methods for multipollutant analysis and evaluation, Marcel Dekker, New York.

Babbitt, C. W., Lindner, A. S., 2005. A life cycle inventory of coal used for electricity production in Florida. J. Clean. Prod. 13 (9), 903-912.

Banos, R., Manzano-Agugliaro, F., Montoya, F. G., Gil, C., Alcayde, A., Gómez, J., 2011. Optimization methods applied to renewable and sustainable energy: A review. Renew. Sust. Energ. Rev. 15 (4), 1753-1766.

Barreto, L., Makihira, A., Riahi, K., 2003. The hydrogen economy in the 21 st century: a sustainable development scenario. Int. J. Hydrogen Energ. 28 (3), 267-284.

Bazmi, A. A., Zahedi, G., 2011. Sustainable energy systems: Role of optimization modeling techniques in power generation and supply - A review. Renew. Sust. Energ. Rev. 15 (8), 3480-3500.

Beccali M., Cellura M., Ardente D., 1998. Decision making in energy planning: the ELECTRE multicriteria analysis approach compared to a FUZZY-SETS methodology. Energ. Convers. Manage. 39 (16-18), 1869-1881.

Belton V., Stewart T.J., 2002. Multiple Criteria Decision Analysis: An Integrated Approach, Kluwer Academic Publications, Boston.

Benetto E, Rousseaux P., Blondin J., 2004. Life cycle assessment of coal by-products based electric power production scenarios. Fuel 83, 957-970. 
Bernal-Agustín, J. L., Dufo-López, R., 2009. Simulation and optimization of stand-alone hybrid renewable energy systems. Renew. Sust. Energ. Rev. 13 (8), 2111-2118.

Bhattacharyya, S. C., Timilsina, G. R., 2010. A review of energy system models. Int. J. Energ. Sec. Manage. 4 (4), 494-518.

Blengini, G. A., 2008. Using LCA to evaluate impacts and resources conservation potential of composting: a case study of the Asti District in Italy. Resour. Conserv. Recy. 52 (12), 1373-1381.

Blengini, G. A., Di Carlo, T., 2010. The changing role of life cycle phases, subsystems and materials in the LCA of low energy buildings. Energ. Buildings 42 (6), 869-880.

Bogetoft P., Pruzan, P.M., 1997. Planning with Multiple Criteria: Investigation, Communication and Choice, Handelshøjskolens forlag, København.

Böhringer, C., 1998. The synthesis of bottom-up and top-down in energy policy modeling. Energ. Econ. 20 (3), 233-248.

Boudghene Stambouli, A., Traversa, E., 2002. Fuel cells, an alternative to standard sources of energy. Renew. Sust. Energ. Rev. 6 (3), 295-304.

Boustead I., 1995. Life-cycle assessment: An overview. Energ. World 7-11.

Bravi, M., Basosi, R. 2014. Environmental impact of electricity from selected geothermal power plants in Italy. J. Clean. Prod. 66, 301-308.

Bréchet, T., Tulkens, H., 2009. Beyond BAT: Selecting optimal combinations of available techniques, with an example from the limestone industry. J. Environ. Manage. 90 (5), 1790-1801.

Cai, Y. P., Huang, G. H., Lin, Q. G., Nie, X. H., Tan, Q., 2009. An optimization-model-based interactive decision support system for regional energy management systems planning under uncertainty. Expert Syst. Appl. 36 (2), 3470-3482.

Cashmore, M., 2004. The role of science in environmental impact assessment: process and procedure versus purpose in the development of theory. Environ. Impact Assess. 24 (4), 403-426.

Catrinu M.D., 2006. Decision Aid for Planning Local Energy Systems: Application of Multi- Criteria Decision Analysis, Doctoral Thesis, Norwegian University of Science and Technology, Faculty of Information Technology, Mathematics and Electrical Engineering, Department of Electrical Power Engineering, Trondheim, Norway.

Cavallaro, F., Ciraolo, L., 2005. A multi-criteria approach to evaluate wind energy plants on an Italian island. Energ. Policy 33 (2), 235-244.

Center of Renewable Energy Sources, 2013a. 19th km Marathonos Ave, Pikermi, Attiki, Greece, GR 19009. http://www.cres.gr/kape/datainfo/, (accessed 24.12.13.).

Center of Renewable Energy Sources, 2013b. 19th km Marathonos Ave, Pikermi, Attiki, Greece, GR 19009. http://www.cres.gr/kape/images/maps/img_pre.htm, (accessed 24.12.13.).

Chicco, G., Mancarella, P., 2009a. Distributed multi-generation: a comprehensive view. Renew. Sust. Energ. Rev. 13 (3), 535-551.

Chicco, G., Mancarella, P., 2009b. Matrix modelling of small-scale trigeneration systems and application to operational optimization. Energy, 34 (3), 261-273. 
Clift R., 1998. Life cycle assessment - how to slim down your ecoprofile. Institution of Chemical Engineers Environmental Protection Bulletin, 9-13.

Cloquell-Ballester, V. A., Monterde-Díaz, R., Cloquell-Ballester, V. A., Santamarina-Siurana, M. C., 2007. Systematic comparative and sensitivity analyses of additive and outranking techniques for supporting impact significance assessments. Environ. Impact Assess. 27 (1), 62-83.

Cormio C., Dicorato M., Minoia A., Trovato M., 2003. A regional energy planning methodology including renewable energy sources and environmental constraints. Renew. Sust. Energ. Rev. 7, 99130.

Cucchiella, F., D'Adamo, I., Lenny Koh, S. C., 2013. Environmental and economic analysis of building integrated photovoltaic systems in Italian regions. J. Clean. Prod. http://dx.doi.org/10.1016/j.jclepro.2013.10.043.

Daniel, T. E., Goldberg, H. M., 1981. Dynamic equilibrium energy modeling: The Canadian BALANCE model. Oper. Res. 29 (5), 829-852.

Dall'O, G., Norese, M. F., Galante, A., Novello, C., 2013. A Multi-Criteria Methodology to Support Public Administration Decision Making Concerning Sustainable Energy Action Plans. Energies 6 (8), 4308-4330.

Dascalaki, E., Balaras, C. A., 2004. XENIOS - a methodology for assessing refurbishment scenarios and the potential of application of RES and RUE in hotels. Energ. Buildings 36 (11), 1091-1105.

Debacker, W., Allacker, K., Spirinckx, C., Geerken, T., De Troyer, F., 2013. Identification of Environmental and Financial Cost Efficient Heating and Ventilation Services for a Typical Residential Building in Belgium. J. Clean. Prod. 57, 188-199.

De Benedetto, L., Klemeš, J., 2009. The Environmental Performance Strategy Map: an integrated LCA approach to support the strategic decision-making process. J. Clean. Prod. 17 (10), 900-906.

Delaby O., Smith R., 1995. Minimization of flue gas emissions. Process Saf. Environ. 73, 21-32.

Delucchi, M. A., Jacobson, M. Z., 2011. Providing all global energy with wind, water, and solar power, Part II: Reliability, system and transmission costs, and policies. Energ. Policy 39 (3), 11701190.

de Lucena, A. F. P., Schaeffer, R., Szklo, A. S., 2010. Least-cost adaptation options for global climate change impacts on the Brazilian electric power system. Global Environ. Chang. 20 (2), 342-350.

Demir, N., Taşkin, A., 2013. Life Cycle Assessment of Wind Turbines in Pınarbaşı-Kayseri. J. Clean. Prod. 54, 253-263.

Descamps, C., Bouallou, C., Kanniche, M., 2008. Efficiency of an Integrated Gasification Combined Cycle (IGCC) power plant including $\mathrm{CO}_{2}$ removal. Energy 33 (6), 874-881.

Diakoulaki D., Antunes C.H., Martins A., 2005. MCDA and energy planning, in: Figueira J., Greco S., Ehrgott M. (Eds.), Multi-criteria decision analysis: state of the art surveys. Springer, New York, pp. 859-898.

Diakoulaki D., Karangelis F., 2007. Multi-criteria decision analysis and cost-benefit analysis of alternative scenarios for the power generation sector in Greece. Renew. Sust. Energ. Rev. 11 (4), 716727. 
Djuric Ilic, D., Dotzauer, E., Trygg, L., Broman, G., 2014. Introduction of large-scale biofuel production in a district heating system-an opportunity for reduction of global greenhouse gas emissions. J. Clean. Prod. 64, 552-561.

Dondi, D., Bertacchini, A., Brunelli, D., Larcher, L., Benini, L., 2008. Modeling and optimization of a solar energy harvester system for self-powered wireless sensor networks. IEEE Trans. Ind. Electron. 55 (7), 2759-2766.

Dovì, V. G., Friedler, F., Huisingh, D., Klemeš, J. J. 2009. Cleaner energy for sustainable future. J. Clean. Prod. 17 (10), 889-895.

Driscoll, C. T., Whitall, D., Aber, J., Boyer, E., Castro, M., Cronan, C., Ollinger, S., 2003. Nitrogen pollution in the northeastern United States: Sources, effects, and management options. BioScience 53 (4), 357-374.

European Commission, DGXII, Science, Research and Development, JOULE, 1995. ExternE, Externalities of Energy. http://www.externe.jrc.es/, http://www.externe.info/, (accessed 15.09.13.).

Evans, A., Strezov, V., Evans, T. J., 2009. Assessment of sustainability indicators for renewable energy technologies. Renew. Sust. Energ. Rev. 13 (5), 1082-1088.

Faé Gomes, G. M., Faria Vilela, A. C., Zen, L. D., Osório, E., 2012. Aspects for a cleaner production approach for coal and biomass use as a decentralized energy source in southern Brazil. J. Clean. Prod. $47,85-95$.

Fingersh, L. J., Hand, M. M., Laxson, A. S., 2006. Wind turbine design cost and scaling model, National Renewable Energy Laboratory, Golden.

Furuholt E., 1995. Life cycle assessment of gasoline and diesel. Resour. Conserv. Recy. 14, 251-263.

Gebreslassie, B. H., Guillén-Gosálbez, G., Jiménez, L., Boer, D., 2009. Design of environmentally conscious absorption cooling systems via multi-objective optimization and life cycle assessment. Appl. Energ. 86 (9), 1712-1722.

Georgakellos, D. A., 2012. Climate change external cost appraisal of electricity generation systems from a life cycle perspective: the case of Greece. J. Clean. Prod. 32, 124-140.

Georgopoulou, E., Mirasgedis, S., Sarafidis, Y., Hontou, V., Gakis, N., Lalas, D. P., Mavrotas, G., 2007. A decision-aid framework to provide guidance for the enhanced use of best available techniques in industry. Environ. Manage. 40 (3), 413-429.

Georgopoulou E., Sarafidis Y., Diakoulaki D., 1998. Design and implementation of a group DSS for sustaining renewable energies exploitation. Eur. J. Oper. Res. 109 (2), 483-500.

Geothermal Electricity (GEOELEC), 2013. http://www.geoelec.eu/wp-content/uploads/2012/01/7.Geothermal-prospects-of-Milos-Nisyros-Lesvos-Methana-Spyridonos.pdf, (accessed 30.12.13.).

Ghiassi, M. D. K. Z., Zimbra, D. K., Saidane, H., 2006. Medium term system load forecasting with a dynamic artificial neural network model. Electr. Pow. Syst. Res. 76 (5), 302-316.

Giampietro, M., Mayumi, K., Munda, G., 2006. Integrated assessment and energy analysis: quality assurance in multi-criteria analysis of sustainability. Energy 31 (1), 59-86. 
Giannantoni C., Lazzaretto A., Macor A., Mirandola A., Stoppato A., Tonon S., Ulgiati S., 2005. Multi-criteria approach for the improvement of energy systems design. Energy 30 (10), 1989-2016.

Giner-Santonja, G., Aragonés-Beltrán, P., Niclós-Ferragut, J., 2012. The application of the analytic network process to the assessment of best available techniques. J. Clean. Prod. 25, 86-95.

Golonka K., 1996. Strategies for treatment of smelter gases containing sulphur dioxide - a technoéconomie study. Ph.D. thesis, Department of Chemical Engineering, Monash University, Melbourne.

Golonka K. Brennan, D. J., 1996. Application of life cycle assessment to process selection for pollutant treatment: A case study of sulphur dioxide emissions from Australian metallurgical smelters. T. I. Chem. Eng-Lond, Part B, 74, 105-119.

Golonka K., Brennan D. J., 1997. Costs and environmental impacts in pollutant treatment: A case study of sulphur dioxide emissions from metallurgical smelters. T. I. Chem. Eng-Lond, Part B, 75, 232-244.

Graedel T.E., Allenby, B.R., 1995. Industrial Ecology, Englewood Cliffs, Prentice Hall, New Jersey.

Greening, L. A., Bernow, S., 2004. Design of coordinated energy and environmental policies: use of multi-criteria decision-making. Energ. Policy 32 (6), 721-735.

Goedkoop, M., Effting, S., Collignon, M., 2000. The Eco-indicator 99: A Damage Oriented Method for Life-cycle Impact Assessment: Manual for Designers, PRé Consultants BV, Amersfoort, The Netherlands.

Goedkoop, M., Spriensma, R. 2001. The eco-indicator 99: A damage oriented method for life cycle impact assessment: Methodology report, PRe' Consultants BV, Amersfoort, The Netherlands.

Gong, D. W., Zhang, Y., Qi, C. L., 2010. Environmental/economic power dispatch using a hybrid multi-objective optimization algorithm. Int. J. Elec. Power 32 (6), 607-614.

González-Monroy, L. I., Cordoba, A., 2002. Financial costs and environmental impact optimization of the energy supply systems. Int. J. Energ. Res. 26 (1), 27-44.

Hadjipaschalis, I., Poullikkas, A., Efthimiou, V., 2009. Overview of current and future energy storage technologies for electric power applications. Renew. Sust. Energ. Rev. 13 (6), 1513-1522.

Haralambopoulos, D. A., Polatidis, H., 2003. Renewable energy projects: structuring a multi-criteria group decision-making framework. Renew. Energ. 28 (6), 961-973.

Hartman, R. S. 1979. Frontiers in energy demand modeling. Annu. Rev. Energy, 4 (1), 433-466.

Hartog J.A., Hinloopen E., Nijkamp P., 1989. A sensitivity analysis of multi-criteria choice-methods. An application on the basis of the optimal site selection for a nuclear power plant. Energ. Econ. 293300 .

Hellenic Statistical Authority, 2013. http://www.statistics.gr/portal/page/portal/ESYE/PAGEcensus2011 (accessed 30.12.13.).

Hiremath R.B., Shikhab S., Ravindranath N.H., 2007. Decentralized energy planning: modelling and application - a review. Renew. Sust. Energ. Rev. 11 (5), 729-752.

Hugo, A., Rutter, P., Pistikopoulos, S., Amorelli, A., Zoia, G., 2005. Hydrogen infrastructure strategic planning using multi-objective optimization. Int. J. Hydrogen Energ. 30 (15), 1523-1534. 
Huntzinger, D. N., Eatmon, T. D., 2009. A life-cycle assessment of Portland cement manufacturing: comparing the traditional process with alternative technologies. J. Clean. Prod. 17 (7), 668-675.

Huppes G., 1996. LCA yesterday, today and tomorrow, Centre of environmental science, Leiden University, Leiden.

Hur, T., Lee, J., Ryu, J., Kwon, E., 2005. Simplified LCA and matrix methods in identifying the environmental aspects of a product system. J. Environ. Manage. 75 (3), 229-237.

Hutchins, M. J., Sutherland, J. W., 2008. An exploration of measures of social sustainability and their application to supply chain decisions. J. Clean. Prod. 16 (15), 1688-1698.

Iribarren, D., Vázquez-Rowe, I., 2013. Is labor a suitable input in LCA+ DEA studies? Insights on the combined use of economic, environmental and social parameters. Social Sciences 2 (3), 114-130.

ISO International Standard 14040, 1997. Environmental management - Life cycle assessment Principles and framework, International Organisation for Standardisation (ISO), Geneva.

Jacobson, M. Z., Delucchi, M. A., 2011. Providing all global energy with wind, water, and solar power, Part I: Technologies, energy resources, quantities and areas of infrastructure, and materials. Energ. Policy 39 (3), 1154-1169.

Jebaraj S., Iniyan S., 2006. A review of energy models. Renew. Sust. Energ. Rev. 10 (4), 281-311.

Jeswani, H. K., Azapagic, A., Schepelmann, P., Ritthoff, M., 2010. Options for broadening and deepening the LCA approaches. J. Clean. Prod. 18 (2), 120-127.

Kaebernick, H., Anityasari, M., Kara, S., 2002. A technical and economic model for End-of-Life (EOL) options of industrial products. Int. J. Environ. Sustain. Dev. 1 (2), 171-183.

Kahraman, C., 2008. Multi-criteria decision making methods and fuzzy sets, in Fuzzy Multi-Criteria Decision Making, Springer US, pp. 1-18.

Kaldellis, J. K., 2004. Optimum technoeconomic energy autonomous photovoltaic solution for remote consumers throughout Greece. Energ. Convers. Manage. 45 (17), 2745-2760.

Kaldellis J.K, Kavadias K. A., 2001. Optimal wind-hydro solution for Aegean Sea Island's electricitydemand fulfillment. Appl. Energ. 70, 333-354.

Kaldellis, J. K., Simotas, M., Zafirakis, D., Kondili, E., 2009. Optimum autonomous photovoltaic solution for the Greek islands on the basis of energy pay-back analysis. J. Clean. Prod. 17 (15), 13111323.

Kaldellis, J. K., Zafirakis, D., 2007. Optimum energy storage techniques for the improvement of renewable energy sources-based electricity generation economic efficiency. Energy 32 (12), 22952305 .

Karaggelis F., 2004. Multi-criteria evaluation of expansion scenarios of the Greek electricity sector, MSc Thesis, National Technical University of Athens, Athens.

Karlsson, R., Luttropp, C., 2006. EcoDesign: what's happening? An overview of the subject area of EcoDesign and of the papers in this special issue. J. Clean. Prod. 14 (15), 1291-1298.

Katsaprakakis, D. A., 2012. A review of the environmental and human impacts from wind parks. A case study for the Prefecture of Lasithi, Crete. Renew. Sust. Energ. Rev. 16 (5), 2850-2863. 
Kavrakoglu I., 1983. Multiobjective strategies in power systems planning. Eur. J. Oper. Res. 12, 159170.

Kaya, T., Kahraman, C., 2011. Multicriteria decision making in energy planning using a modified fuzzy TOPSIS methodology. Expert Syst. Appl. 38 (6), 6577-6585.

Keoleian G.A., 1993. The application of life cycle assessment to design. J. Clean. Prod. 3 (4), 143-149.

Khan F.I., Natrajan B. R., Revathi P., 2001. GreenPro: a new methodology for cleaner and greener process design. J. Loss. Prevent. Proc. 14 (4), 307-328.

Khan F.I., Sadiq R., and Husain T., 2002. GreenPro-I: a risk-based life cycle assessment and decisionmaking methodology for process plant design. Environ. Modell. Softw. 17 (8), 669-692.

Khella A.F.A, 1997. Energy planning policies with environmental Considerations. Energ. Policy, 25 (1), 105-115.

Kirubakaran, A., Jain, S., Nema, R. K., 2009. A review on fuel cell technologies and power electronic interface. Renew. Sust. Energ. Rev. 13 (9), 2430-2440.

Kjaerheim, G., 2005. Cleaner production and sustainability. J. Clean. Prod. 13 (4), 329-339.

Kniel G.E., Delmarco K., Pétrie J. G., 1996. Life cycle assessment applied to process design: Environmental and economic analysis and optimisation of a nitric acid plant. Environ. Prog. 15 (4), 221-228.

Knight, P., Jenkins, J. O., 2009. Adopting and applying eco-design techniques: a practitioners perspective. J. Clean. Prod. 17 (5), 549-558.

Kooijman-van Dijk, A. L., Clancy, J., 2010. Impacts of electricity access to rural enterprises in Bolivia, Tanzania and Vietnam. Energ. Sust. Dev. 14 (1), 14-21.

Koroneos C., Michailidis M., and Moussiopoulos N., 2004. Multi-objective optimization in energy systems: The case study of Lesvos island, Greece. Renew. Sust. Energ. Rev. 8, 91-100.

Koroneos, C. J., \& Nanaki, E. A., 2012. Life cycle environmental impact assessment of a solar water heater. J. Clean. Prod. 37, 154-161.

Koroneos C., Zairis N., Charaklias P., Moussiopoulos N., 2005. Optimization of energy production system in the Dodecanese Islands. Renew. Energ. 30, 195-210.

Kowalski, K., Stagl, S., Madlener, R., Omann, I., 2009. Sustainable energy futures: Methodological challenges in combining scenarios and participatory multi-criteria analysis. Eur. J. Oper. Res. 197 (3), $1063-1074$.

Krewitt, W., 2002. External costs of energy-Do the answers match the questions? Looking back at 10 years of ExternE. Energ. Policy 30 (10), 839-848.

Kumar, A., Jones, D. D., Hanna, M. A., 2009. Thermochemical biomass gasification: a review of the current status of the technology. Energies 2 (3), 556-581.

Kydes, A.S., 1990. Flow models. Energy 15, 561-571. 
Kyriakis N., Tsilingiridis G., Martinopoulos G., 2004. Life cycle environmental impact of a thermosyphonic domestic solar hot water system in comparison with electrical and gas water heating. Renew. Energ. 29 (8), 1277-1288.

Ladenburg, J., Dubgaard, A., 2007. Willingness to pay for reduced visual disamenities from offshore wind farms in Denmark. Energ. Policy 35 (8), 4059-4071.

Lazzaretto, A., Toffolo, A., 2004. Energy, economy and environment as objectives in multi-criterion optimization of thermal systems design. Energy 29 (8), 1139-1157.

Lee J., O'Callaghan P., Allen D., 1995. Critical review of life cycle analysis and assessment techniques and their application to commercial activities. Resour. Conserv. Recy. 13, 37-56.

Lehtila A., Pirila P., 1996. Reducing energy related emissions: using an energy systems optimization model to support policy planning in Finland. Energ. Policy 24, 805-819.

Li, X., 2005. Diversification and localization of energy systems for sustainable development and energy security. Energ. Policy, 33(17), 2237-2243.

Li, Z. S., Zhang, G. Q., Li, D. M., Zhou, J., Li, L. J., Li, L. X., 2007. Application and development of solar energy in building industry and its prospects in China. Energ. Policy 35 (8), 4121-4127.

Lim, S. R., Kim, Y. R., Woo, S. H., Park, D., Park, J. M., 2013. System optimization for eco-design by using monetization of environmental impacts: a strategy to convert bi-objective to single-objective problems. J. Clean. Prod. 39, 303-311.

Liming, H., 2009. Financing rural renewable energy: a comparison between China and India. Renew. Sust. Energ. Rev. 13 (5), 1096-1103.

Lin, Q. G., Huang, G. H., Bass, B., Qin, X. S., 2009. IFTEM: an interval-fuzzy two-stage stochastic optimization model for regional energy systems planning under uncertainty. Energ. Policy, 37 (3), 868-878.

Liu, P., Georgiadis, M. C., Pistikopoulos, E. N., 2010. Advances in energy systems engineering. Ind. Eng. Chem. Res. 50 (9), 4915-4926.

Liu, P., Pistikopoulos, E. N., Li, Z., 2009. A mixed-integer optimization approach for polygeneration energy systems design. Comput. Chem. Eng. 33 (3), 759-768.

Liu, X., Wen, Z., 2012. Best available techniques and pollution control: a case study on China's thermal power industry. J. Clean. Prod. 23 (1), 113-121.

Løken, E., (2007). Use of multi-criteria decision analysis methods for energy planning problems. Renew. Sust. Energ. Rev. 11 (7), 1584-1595.

Lombardi L., 2002. Life cycle assessment comparison of technical solutions for $\mathrm{CO}_{2}$ emissions reduction in power generation. Energ. Convers. Manage. 44 (1), 93-108.

Lozano, M. A., Ramos, J. C., Serra, L. M., 2010. Cost optimization of the design of CHCP (combined heat, cooling and power) systems under legal constraints. Energy 35(2), 794-805.

Lund, H., 2005. Large-scale integration of wind power into different energy systems. Energy 30 (13), $2402-2412$. 
Lund, H., Duić, N., Graça Carvalho, M. D., 2007. Two energy system analysis models: a comparison of methodologies and results. Energy 32 (6), 948-954.

Luttropp, C., Lagerstedt, J., 2006. EcoDesign and The Ten Golden Rules: generic advice for merging environmental aspects into product development. J. Clean. Prod. 14 (15), 1396-1408.

Maceira, M. E. P., Terry, L. A., Costa, F. S., Damázio, J. M., Melo, A. C. G., 2002. Chain of optimization models for setting the energy dispatch and spot price in the Brazilian system, in Proceedings of the Power System Computation Conference-PSCC 2, pp. 24-28.

Mamlook R., Mohsen M.S., Akash B.A., 2001. Evaluation of electrical power production system options in Jordan using fuzzy sets methodology. Energy 26 (6), 619-632.

Manne, A. S., Richels, R. G., Weyant, J. P., 1979. Energy policy modeling: a survey. Oper. Res. 27 (1), 1-36.

Markandya A., 1990. Environmental costs and power systems planning. Utilities Policy, 1 (1), 13-27.

Matsuhashi R., Hikita B., Ishitani H., 1996. Model analysis for sustainable energy supply taking resource and environmental constraints into consideration. Energ. Convers. Manage. 37 (6-8), $1253-$ 1258.

McDougall, G. H., Claxton, J. D., Ritchie, J. B., Anderson, C. D., 1981. Consumer energy research: a review. J. Consum. Res., 343-354.

Meier, P., Mubayi V., 1983. Modelling energy-economic interactions in developing countries: A linear programming approach. Eur. J. Oper. Res. 13, 41-59.

Metaxiotis, K., Kagiannas, A., Askounis, D., Psarras, J., 2003. Artificial intelligence in short term electric load forecasting: a state-of-the-art survey for the researcher. Energ. Convers. Manage. 44 (9), $1525-1534$.

Millet, D., Bistagnino, L., Lanzavecchia, C., Camous, R., Poldma, T., 2007. Does the potential of the use of LCA match the design team needs? J. Clean. Prod. 15 (4), 335-346.

Mohammad Rozali, N. E., Wan Alwi, S. R., Abdul Manan, Z., Klemeš, J. J., Hassan, M. Y., 2013. Optimal sizing of hybrid power systems using power pinch analysis. J. Clean. Prod., http://dx.doi.org/10.1016/j.jclepro.2013.12.028.

Momirlan, M., Veziroglu, T. N., 2005. The properties of hydrogen as fuel tomorrow in sustainable energy system for a cleaner planet. Int. J. Hydrogen Energ. 30 (7), 795-802.

Moradi, M. H., Abedini, M., 2012. A combination of genetic algorithm and particle swarm optimization for optimal DG location and sizing in distribution systems. Int. J. Elec. Power 34 (1), 6674.

Muela, E., Schweickardt, G., Garces, F., (2007). Fuzzy possibilistic model for medium-term power generation planning with environmental criteria. Energ. Policy 35 (11), 5643-5655.

Mueller-Langer, F., Tzimas, E., Kaltschmitt, M., Peteves, S., 2007. Techno-economic assessment of hydrogen production processes for the hydrogen economy for the short and medium term. Int. J. Hydrogen Energ. 32 (16), 3797-3810.

Muñoz, J. R., von Spakovsky, M. R., 2010. The application of decomposition to the large scale synthesis/design optimization of aircraft energy systems. Int. J. Thermodyn. 4 (2), 61-76. 
Narodoslawsky, M., Krotscheck, C., 2004. What can we learn from ecological valuation of processes with the sustainable process index (SPI) - the case study of energy production systems. J. Clean. Prod. $12(2), 111-115$.

Nijkamp P., Volwahsen A., 1990. New directions in integrated regional energy planning. Energ. Policy, 764-773.

Ochoa, L. F., Harrison, G. P., 2011. Minimizing energy losses: Optimal accommodation and smart operation of renewable distributed generation. IEEE Trans. Power Syst. 26 (1), 198-205.

Odeh, N. A., Cockerill, T. T., 2008. Life cycle analysis of UK coal fired power plants. Energ. Convers. Manage. 49 (2), 212-220.

Oikonomou, E. K., Kilias, V., Goumas, A., Rigopoulos, A., Karakatsani, E., Damasiotis, M., Marini, N., 2009. Renewable energy sources (RES) projects and their barriers on a regional scale: The case study of wind parks in the Dodecanese islands, Greece. Energ. policy, 37 (11), 4874-4883.

Østergaard, P. A., 2009. Reviewing optimisation criteria for energy systems analyses of renewable energy integration. Energy 34 (9), 1236-1245.

Pacca, S., \& Horvath, A., 2002. Greenhouse gas emissions from building and operating electric power plants in the Upper Colorado River Basin. Environ. Sci. Technol. 36 (14), 3194-3200.

Papadopoulos, A., Karagiannidis, A., 2008. Application of the multi-criteria analysis method Electre III for the optimisation of decentralised energy systems. Omega 36 (5), 766-776.

Pehnt, M., 2006. Dynamic life cycle assessment (LCA) of renewable energy technologies. Renew. Energ. 31 (1), 55-71.

Pękala, Ł. M., Tan, R. R., Foo, D. C., Jeżowski, J. M., 2010. Optimal energy planning models with carbon footprint constraints. Appl. Energ. 87 (6), 1903-1910.

Pesso C., 1993. Life cycle methods and applications: Issues and perspectives. J. Clean. Prod. 7(3-4), 139-142.

Pohekar, S. D., Ramachandran, M., 2004. Application of multi-criteria decision making to sustainable energy planning - a review. Renew. Sust. Energ. Rev. 8 (4), 365-381.

Polatidis, H., Haralambopoulos, D. A., Munda, G., Vreeker, R., 2006. Selecting an appropriate multicriteria decision analysis technique for renewable energy planning. Energy Sources, Part B 1(2), 181 193.

Psarras J., Capros P., Samouilidis J.E., 1990. Multi-criteria analysis using a large-scale energy supply LP model. Eur. J. Oper. Res. 44 (3), 383-394.

Public Power Corporation of Greece (PPC), 2013. Island Prefecture Department 30 Chalkokondili St., Athens, Greece, GR 10432. Available from: www.dei.gr, (accessed 30.12.13.).

Pudjianto, D., Ramsay, C., Strbac, G., 2007. Virtual power plant and system integration of distributed energy resources. IET Renew. Power Gen. 1 (1), 10-16.

Raiko M.O, Gronfors T.H.A., Haukka P., 2003. Development and optimization of power plant concepts for local wet fuels. Biomass Bioenerg. 24, 27-37. 
Ramakumar, R., Abouzahr, I., Ashenayi, K., 1992. A knowledge-based approach to the design of integrated renewable energy systems. IEEE Trans. Energy Conversion 7(4), 648-659.

Reddy, S., Painuly, J. P., 2004. Diffusion of renewable energy technologies-barriers and stakeholders' perspectives. Renew. Energ. 29 (9), 1431-1447.

Ren, H., Zhou, W., Nakagami, K. I., Gao, W., Wu, Q., 2010. Multi-objective optimization for the operation of distributed energy systems considering economic and environmental aspects. Appl. Energ. 87 (12), 3642-3651.

Rentizelas, A. A., Tatsiopoulos, I. P., Tolis, A., 2009. An optimization model for multi-biomass trigeneration energy supply. Biomass Bioenerg. 33 (2), 223-233.

Riaz, A., Zahedi, G., Klemeš, J. J., 2013. A Review of Cleaner Production Methods for the Manufacture of Methanol. J. Clean. Prod. 57, 19-37.

Ribeiro R.A., 1996. Fuzzy multiple attribute decision making: a review and new preference elicitation techniques. Fuzzy Set. Syst. 78, 155-181.

Rivers, N., Jaccard, M., 2005. Combining top-down and bottom-up approaches to energy-economy modeling using discrete choice methods. Energy J., 26 (1), 83-106.

Rosen, M. A., 2001. Energy-and exergy-based comparison of coal-fired and nuclear steam power plants. Exergy, An International Journal 1 (3), 180-192.

Roy B., Bouyssou D., 1986. Comparison of two decision-aid models applied to a nuclear power plant siting example. Eur. J. Oper. Res. 25, 200-215.

Samouilidis, J., Mitropoulos, C., 1982. Energy-economy models: A survey. Eur. J. Oper. Res. 11, 222-232.

San Cristóbal, J. R., 2011. Multi-criteria decision-making in the selection of a renewable energy project in Spain: the Vikor method. Renew. Energ. 36 (2), 498-502.

Santarelli, M., Calì, M., \& Macagno, S., 2004. Design and analysis of stand-alone hydrogen energy systems with different renewable sources. Int. J. Hydrogen Energ. 29 (15), 1571-1586.

Santibañez-Aguilar, J. E., González-Campos, J. B., Ponce-Ortega, J. M., Serna-González, M., ElHalwagi, M. M., 2013. Optimal planning and site selection for distributed multiproduct biorefineries involving economic, environmental and social objectives. J. Clean. Prod. 65, 270-294.

Scheuer, C., Keoleian, G. A., Reppe, P., 2003. Life cycle energy and environmental performance of a new university building: modeling challenges and design implications. Energ. Buildings 35 (10), 1049-1064.

Schulz V., Stehfest H., 1984. Regional energy supply optimization with multiple objectives. Eur. J. Oper. Res. 17, 302-312.

Sea Freight, 2013. seafreightcalculator.com/, (accessed 30.12.13.).

Seager, T. P., Theis, T. L., 2002. A uniform definition and quantitative basis for industrial ecology. J. Clean. Prod. 10 (3), 225-235.

SETAC, Society of Environmental Toxicology and Chemistry, 1993. Guidelines for Life Cycle Assessment: A code of practice, Washington DC. 
Shawwash, Z. K., Siu, T. K., Russell, S. D., 2000. The BC Hydro short term hydro scheduling optimization model. IEEE Trans. Power Syst. 15 (3), 1125-1131.

Sheehan J.J., Duffield J.A., Coulon R.B., Cambreco V.J., 1996. Life-cycle assessment of biodiesel versus petroleum diesel fuel. Proceedings of the 31st intersociety energy conversion conference, 3, pp. 21402143).

Sieniutycz, S., Jezowski, J., 2009. Energy optimization in process systems, Elsevier, Amsterdam.

Siskos J., Hubert Ph., 1983. Multi-criteria analysis of the impacts of energy alternatives: A survey and a new comparative approach. Eur. J. Oper. Res. 13, 278-299.

Skarlis, S., Kondili, E., Kaldellis, J. K., 2012. Small-scale biodiesel production economics: a case study focus on Crete Island. J. Clean. Prod. 20 (1), 20-26.

Soloveitchik D., Ben-Aderet N., Grinman M., Lotov A., 2002. Multiobjective optimization and marginal pollution abatement cost in the electricity sector - An Israeli case study. Eur. J. Oper. Res. 140 (3), 571-583.

Stylos, N., Koroneos, C., 2014. Carbon footprint of polycrystalline photovoltaic systems. J. Clean. Prod. 64, 639-645.

Taha, R. A., Daim, T., 2013. Multi-Criteria Applications in Renewable Energy Analysis, a Literature Review, in: Tugrul, D., Oliver, T., Kim, J. (Eds.), Research and Technology Management in the Electricity Industry, Springer, London, pp. 17-30.

Tanzil, D., Beloff, B. R., 2006. Assessing impacts: Overview on sustainability indicators and metrics. Environ. Qual. Manage. 15 (4), 41-56.

Thabrew, L., Wiek, A., Ries, R., 2009. Environmental decision making in multi-stakeholder contexts: applicability of life cycle thinking in development planning and implementation. J. Clean. Prod. 17 (1), $67-76$.

Thitakamol, B., Veawab, A., Aroonwilas, A., 2007. Environmental impacts of absorption-based $\mathrm{CO}_{2}$ capture unit for post-combustion treatment of flue gas from coal-fired power plant. Int. J. Greenh. Gas Con. 1(3), 318-342.

The European Wind Energy Association (EWEA), 2014. http://www.ewea.org/publications/reports/, (accessed 04.01.14.).

Theodosiou G., Koroneos C., Moussiopoulos N., 2005a. Alternative scenarios analysis concerning different types of fuels used for the coverage of the energy requirements of a typical apartment building in Thessaloniki, Greece. Part I: Fuel consumption and emissions. Build. Environ. 42 (3), $1522-1530$.

Theodosiou G., Koroneos C., Moussiopoulos N., 2005b. Alternative scenarios analysis concerning different types of fuels used for the coverage of the energy requirements of a typical apartment building in Thessaloniki, Greece. Part II: life cycle analysis. Build. Environ. 40 (12), 1602-1610.

Theodosiou, G., Koroneos, C., Stylos, N., 2014. Environmental impacts of the Greek electricity generation sector. Sustain. Energy Technol. Assess. 5, 19-27.

The Wind Power, 2013. http://www.thewindpower.net/country_windfarms_en_15_greece.php, (accessed 30.12.13.). 
Therkelsen, P., McKane, A., Sabouni, R., Evans, T., Scheihing, P., 2013. Assessing the Costs and Benefits of the Superior Energy Performance Program. Energ. Policy, 57, 318-328.

Thorin, E., Brand, H., Weber, C., 2005. Long-term optimization of cogeneration systems in a competitive market environment. Appl. Energ. 81 (2), 152-169.

Tiris M., Atangunduz G., Dincer I., 1994. Energy, economy and environment modeling: applications for Turkey. Energy 19, 1005-1009.

Turton, H., Barreto, L., 2006. Long-term security of energy supply and climate change. Energ. Policy 34 (15), 2232-2250.

Van Veldhuizen, D. A., Lamont, G. B., 2000. Multi-objective evolutionary algorithms: Analyzing the state-of-the-art. Evol. Comput. 8 (2), 125-147.

Varun, Bhat, I. K., Prakash, R., 2009. LCA of renewable energy for electricity generation systems-A review. Renew. Sust. Energ. Rev. 13 (5), 1067-1073.

Vikhorev, K., Greenough, R., Brown, N., 2013. An advanced energy management framework to promote energy awareness. J. Clean. Prod. 43, 103-112.

Vinodh, S., Rathod, G., 2010. Integration of ECQFD and LCA for sustainable product design. J. Clean. Prod. 18 (8), 833-842.

von Blottnitz, H., Curran, M. A., 2007. A review of assessments conducted on bio-ethanol as a transportation fuel from a net energy, greenhouse gas, and environmental life cycle perspective. J. Clean. Prod. 15 (7), 607-619.

Wack, P., 1985. Scenarios: shooting the rapids. Harvard Bus. Rev. 63 (6), 139-150.

Wang, J., Dai, Y., Gao, L., 2008. Parametric analysis and optimization for a combined power and refrigeration cycle. Appl. Energ., 85 (11), 1071-1085.

Wang, J. J., Jing, Y. Y., Zhang, C. F., Shi, G. H., Zhang, X. T. 2008. A fuzzy multi-criteria decisionmaking model for trigeneration system. Energ. Policy 36 (10), 3823-3832.

Wang, J. J., Jing, Y. Y., Zhang, C. F., Zhao, J. H., 2009. Review on multi-criteria decision analysis aid in sustainable energy decision-making. Renew. Sust. Energ. Rev. 13 (9), 2263-2278.

Wang, X., Chen, Y., Sui, P., Gao, W., Qin, F., Wu, X., Xiong, J., 2013. Efficiency and sustainability analysis of biogas and electricity production from a large-scale biogas project in China: an emergy evaluation based on LCA. J. Clean. Prod. 65, 234-245.

Wang, L., Singh, C., 2008. Stochastic economic emission load dispatch through a modified particle swarm optimization algorithm. Electr. Pow. Syst. Res. 78 (8), 1466-1476.

Wang, M., Wu, M., Huo, H., 2007. Life-cycle energy and greenhouse gas emission impacts of different corn ethanol plant types. Environ. Res. Lett. 2 (2), 24 (1), 1-13.

Wilde, M., 2008. Best available techniques (BAT) and coal-fired power stations: can the energy gap be plugged without increasing emissions? J. Environ. Law 20 (1), 87-114. 
Wursthorn, S., Poganietz, W. R., Schebek, L., 2011. Economic-environmental monitoring indicators for European countries: A disaggregated sector-based approach for monitoring eco-efficiency. Ecol. Econ. 70 (3), 487-496.

Xydis, G., 2013. On the exergetic capacity factor of a wind-Solar power generation system. J. Clean. Prod. 47, 437-445.

Yang, H., Wei, Z., Chengzhi, L., 2009. Optimal design and techno-economic analysis of a hybrid solar-wind power generation system. Appl. Energ. 86 (2), 163-169.

Yusoff, S., 2006. Renewable energy from palm oil-innovation on effective utilization of waste. J. Clean. Prod. 14 (1), 87-93.

Zionts, S., Deshpande D., 1978. An application of multiple criteria problem solving to energy planning. Paper presented at the Eighth International Conference of IFORS, Toronto, Canada.

Zuwała, J., 2012. Life cycle approach for energy and environmental analysis of biomass and coal cofiring in CHP plant with backpressure turbine. J. Clean. Prod. 35, 164-175.

\section{CAPTIONS}

\section{FIGURES}

Fig. 1. Eco-design framework and integration of the environmental aspect as a parameter for minimization.

Fig. 2. Simplified design procedure of a new energy system.

Fig. 3. Basic electricity generation model representation.

Fig. 4. Variation of the electricity generation model where in order to cover the energy needs of a region or of facilities of smaller scale, electricity from a central network is used as well as electricity and/or heat from energy systems that are installed.

Fig. 5. General steps for the design of an energy system based on the life cycle analysis methodology and multi-criteria analysis model.

Fig. 6. General procedure of the mathematical problem and multi-criteria optimization model formulation.

Fig. 7. Life cycle stages for different energy sources and technologies used for electricity, heat generation and emissions of each stage.

Fig. 8. General procedure of acquiring environmental evaluation indices using Eco-Indicator 99 methodology (Goedkoop et al., 2000; Goedkoop \& Spriensma, 2001).

Fig. 9. Map of wind energy potential areas for the island of Rhodes (Center of Renewable Energy Sources, 2013b).

Fig.10. Consumption of electricity in the island of Rhodes.

Fig.11. Optimal participation of each energy source for Rhodes case scenario.

Fig. 12. Weighted environmental damage scores per impact category for the existing and proposed optimized power systems.

Fig. 13. Representation of Cumulative damage assessment per kWh of power produced for the existing and proposed optimized power systems.

\section{TABLES}

Table 1 Criteria for classifying energy systems optimization models and relevant options.

Table 2 Impact and Damage categories EcoIndicator 99 for the environmental evaluation indices applied. 
Table 3 Operation and Maintenance costs for various types of wind turbines (Fingersh et al., 2006).

Table 4 Existing participation of energy sources to the power production system of Rhodes (year 2012).

Table 5 Optimal participation of energy sources to the power production system for the Rhodes case scenario.

Table 6 Weighted environmental damage scores per impact category for the existing system in island of Rhodes (EI 99 H/A).

Table 7 Weighted environmental damage scores per impact category for the system resulting after optimization takes place (EI 99 H/A). 